\title{
ENGINEERING ASPECTS OF GEOTHERMAL DEVELOPMENT IN THE IMPERIAL VALLEY
}

by

MARTIN GOLDSMITH

EQL MEMORANDUM NO. 20

December 1976

Environmental Quality Laboratory CALIFORNIA INSTITUTE OF TECHNOLOGY

Pasadena, California 91125 
ENGTVEERING ASPECTS OF GEOTHERMAL DEVELOPMENT IN THE IMPERTAL VALLEY

by

Martin Goldsmith

EQL MEMORANDUM NO. 20

December 1976

ENVIRONMENTAL OUALTTY LABORATORY

California Institute of Technology

Pasadena, California 91125

Sponsored by

County of Imperial, California

NSF Grant No. AER 75-08793 
CONTENTS

Page

I Introduction 1

II Features of Geothermal Wells in Imperial Valley 2

II Reinjection of Geothermal Fluids in Imperial Valley 11

IV Transmission Pipes 16

$\begin{array}{lll}V & \text { Power Plant Characteristics } & 19\end{array}$

VI Cooling Requirements for Geothermal Power Plants 31

VII Cooling Water Availability in the Imperial Valley 36

VIII Suitability of Irrigation Drain Water for Power Plant Cooling 41

IX Production of Useful Water from Geothermal Resources 45

$\mathrm{X}$ Production of Chemicals from Imperial Valley Geothermal Resources 
The existence of geothermal resources in the Imperial Valley of California has been known for many years. An accelerating pace of exploration has contributed to a belief that major developments are likely. In order to fulfill its function, the County of Imperial has decided to introduce a Geothermal Element into its General Plan. To provide the background necessary for preparing such an element, the County contracted with the University of California at Riverside and the Envirommental Quality Laboratory at the California Institute of Technology to carry out appropriate investigations. These include questions of resource evaluation, engineering development, environmental impact, economics, regulation, and so forth. This document is a collection of reviews of engineering matters pertinent to the County's plan. The various subjects were chosen for their applicability to the plan or to the needs of other workers on the project. By gathering the separate sections together, it is hoped that the information will be more conveniently available and useful to County personnel and others. It is not a comprehensive treatment.

Briefly, the contents include discussions of drilling practice, costs, and land requirements. Brief notes on reinjection and on fluid transmission follow. The section on power plants attempts to give scaling relationships for land area, costs, and performance, according to size and reservoir temperature. The problem of cooling power plants is important, particularly in an arid agricultural area. Cooling requirements, water availability, and water suitability are discussed in turn. The question of the interactions of the hydrologic cycle, withdrawals for cooling, and the Salton Sea are covered in a separate EQL document. Finally, there are sections devoted to nonelectrical uses for the geothermal resources, including production of fresh water and chemicals. The direct uses for geothermal heat are not included. 
The equipment and techniques employed in drilling geothermal wells are similar to those used for oil wells. In many geothermal areas, however, drilling is conducted under difficult conditions. Regions such as Geysers, Ahuachapan, and other volcanic areas contain rock of considerable hardness. The Imperial Valley, however, is underlain by sedimentary material as is commonly found in oil producing areas. The tough volcanic rocks slow drilling rates, accelerate drill bit wear, and consequently cause higher drilling costs. The fissured nature of such formations also frequently make it difficult to maintain bore direction, and can preclude practical directional drilling. Fortunately, most Imperial Valley areas do not suffer from these problems. There good drilling rates can be maintained and directional drilling is possible.

This review will summarize several drilling topics that are important to the work of others in the project. Included are surface area requirements for drilling and well operation, and general cost estimates. This information has been obtained from operators presently active in the Imperial Valley.

\section{Surface Area Required}

In addition to the area required for the drilling itself, a drilling location requires parking, support and storage structures, mud pit, etc. Because rental or other fees for damage must often be paid to a landholder for such area, the drilling operator is generally motivated to minimize his land requirements. It is estimated that about one acre is required to drill a single well. However, because many of the facilities are common to a multiple well operation, only two acres are estimated to be necessary for multiple wells drilled in sequence. Subsequent to drilling, some of this area might be returned to other uses, as only about one-half acre is required around a producing well to allow for service or possible rework. 


\section{Area Coyered by Slant Drilling}

The total amount of offset possible from a given wellhead location is of course not rigidly fixed by any law of nature. Nonetheless, industry practice suggests some guidelines from which estimates can be made. A typical set of constraints might include 1) $1000 \mathrm{ft}$. vertical, to provide a good anchorage for the well; 2) then deviate $3 \% / 100 \mathrm{ft}$. to a maximum of $30^{\circ}$ from vertical; 3) drilling continues along the $30^{\circ}$ tangent. This is illustrated in Figure 1.

For such a configuration, the following table of distances can be constructed.

\section{TABLE 1}

Table of Well offsets (feet)

\section{Depth of We11}

1000

2000

3000

4000

5000

6000

7000

8000
Total Offset

0

282

859

1436

2013

3590

3167

3744
Total Length

1000

2052

3207

4362

5517

6672

7872

9892

From the table it is seen that for a producing horizon at 6000 feet, the possible well offset approximates one-half mile. For a single wellhead location, the data of Table 1 can be used to calculate the square area that can be covered (see sketch). This calculation is plotted in Figure 2. If the angular limit were increased from $30^{\circ}$ to $45^{\circ}$, a substantially

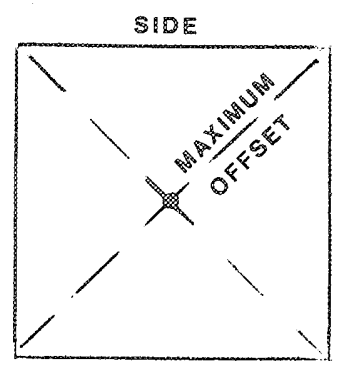


FIGURE 1. GEOMETRY OF SLANT DRILLING

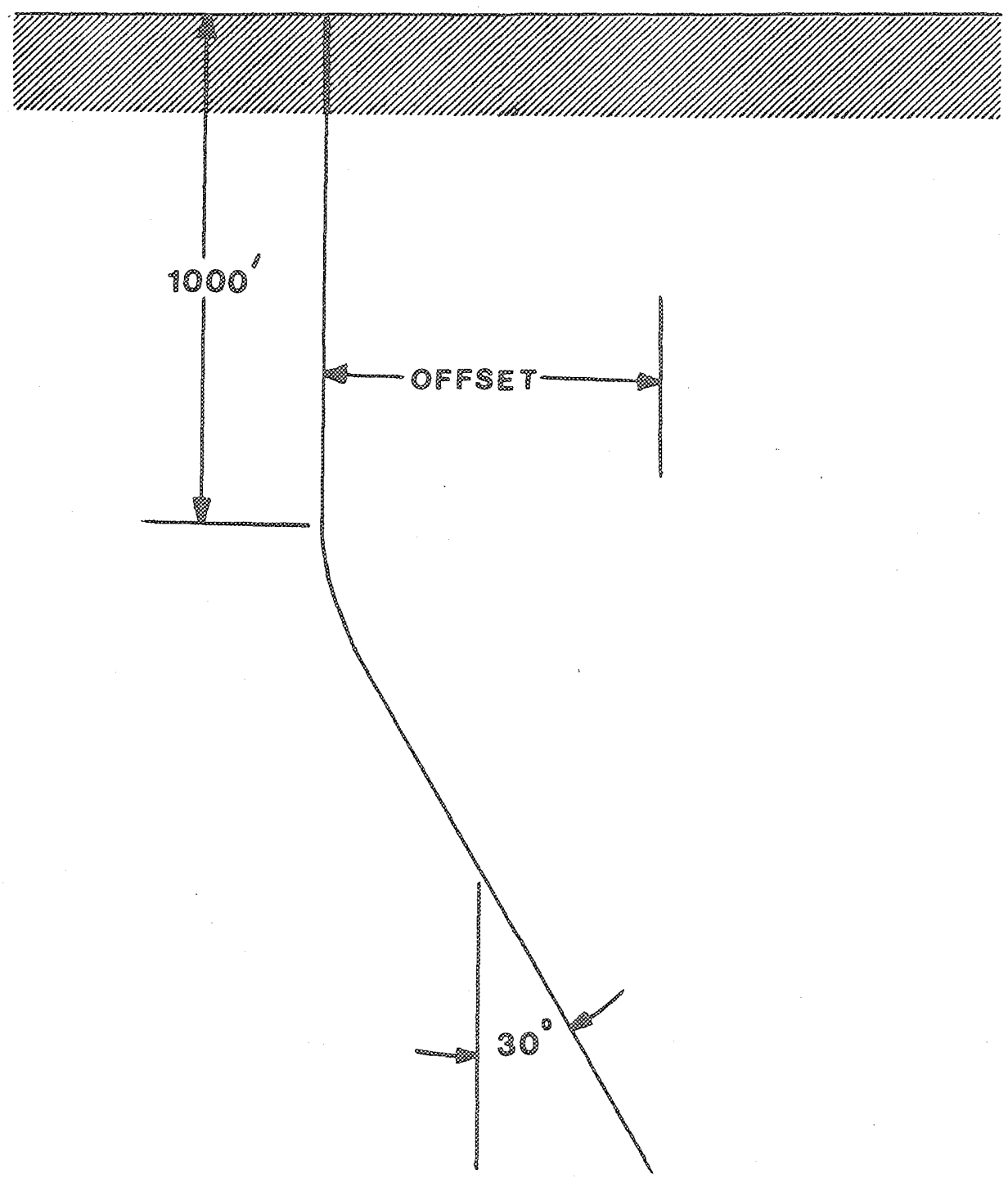


FIGURE 2. AREA COVERAGE FROM SINGLE WELL LOCATION

(assuming a) $1000^{\circ}$ vertical; b) $3^{\circ} / 100^{\circ}$ deviation: and c) named angular limit)

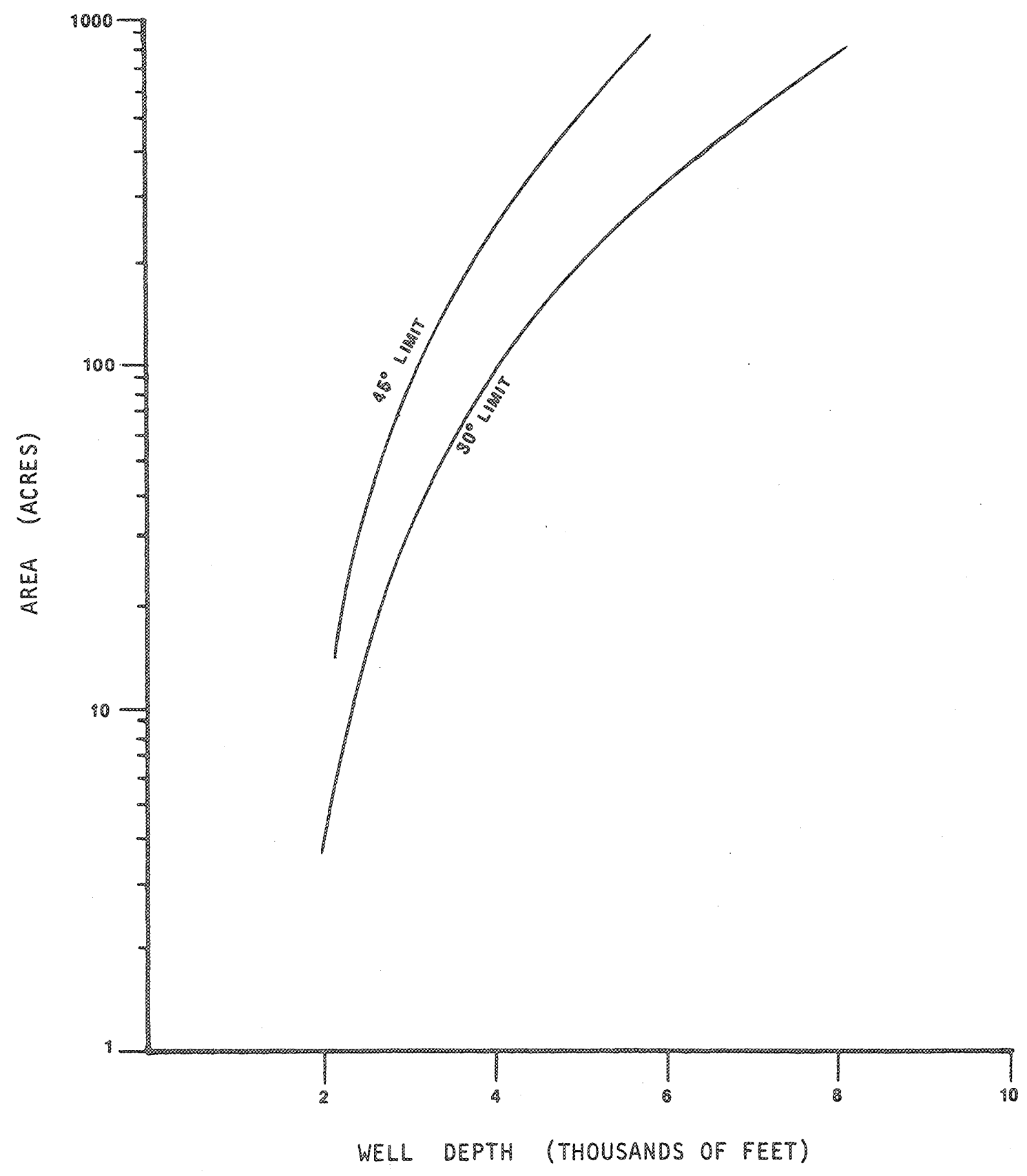


gxeater area can be covered. This is also plotted in Figure 2, for illustration.

Area Required for Producing Field

The information on the area covered from a single wellhead locam tion becomes more meaningful if we consider the area required to produce electric power. Two parameters are important, the equivalent electrical capacity of one well, and the area from which one well can draw (well spacing). In a field which is considered a "good producer" such as Cerro Prieto, an individual well might typically produce enough steam to generate $5 \mathrm{MW}$ of electricity. Reservoirs of lower temperature or permeability might yield less; sometimes a well produces more. Yet this value can illustrate the characteristics of a good field. Well spacing can vary. If the wells are too close, they may draw from the same portion of the reservoix (called interference). Spacing too wide reduces the power available from the field. In some cases, wells are widely spaced so that if they begin to exhaust the surrounding part of the reservoir, additional wells can be interspersed so as to prolong the useful life of the reservoir and the power plant it feeds. At Cerro Prieto, spacing of as little as 10 acres/well is employed; at Geysers, 40 acres/well is more common. No set rule can be given, as each field must be exploited according to physical and economic fact. Figure 3 shows area requirements against electric capacity for the parameters discussed above. The use of Figures 2 and 3 together enables some useful insights to be gained.

As an example, 100 WW has been frequently considered as a basic unit size for commercial geothermal electric generating stations. For $100 \mathrm{MW}$ and well spacing such as that used at Cerro Prieto, it is seen that 200 acres are required. Figure 2 indicates that for producing horizons at 5000 foot depth, a single drilling location will be able to serve the plant. Thus no steam transmission pipe would be necessary 
FIGURE 3. RESERVOTR AREA REQUTREMENTS FOR

ELECTRIC GENERATION (5MW/WELL)

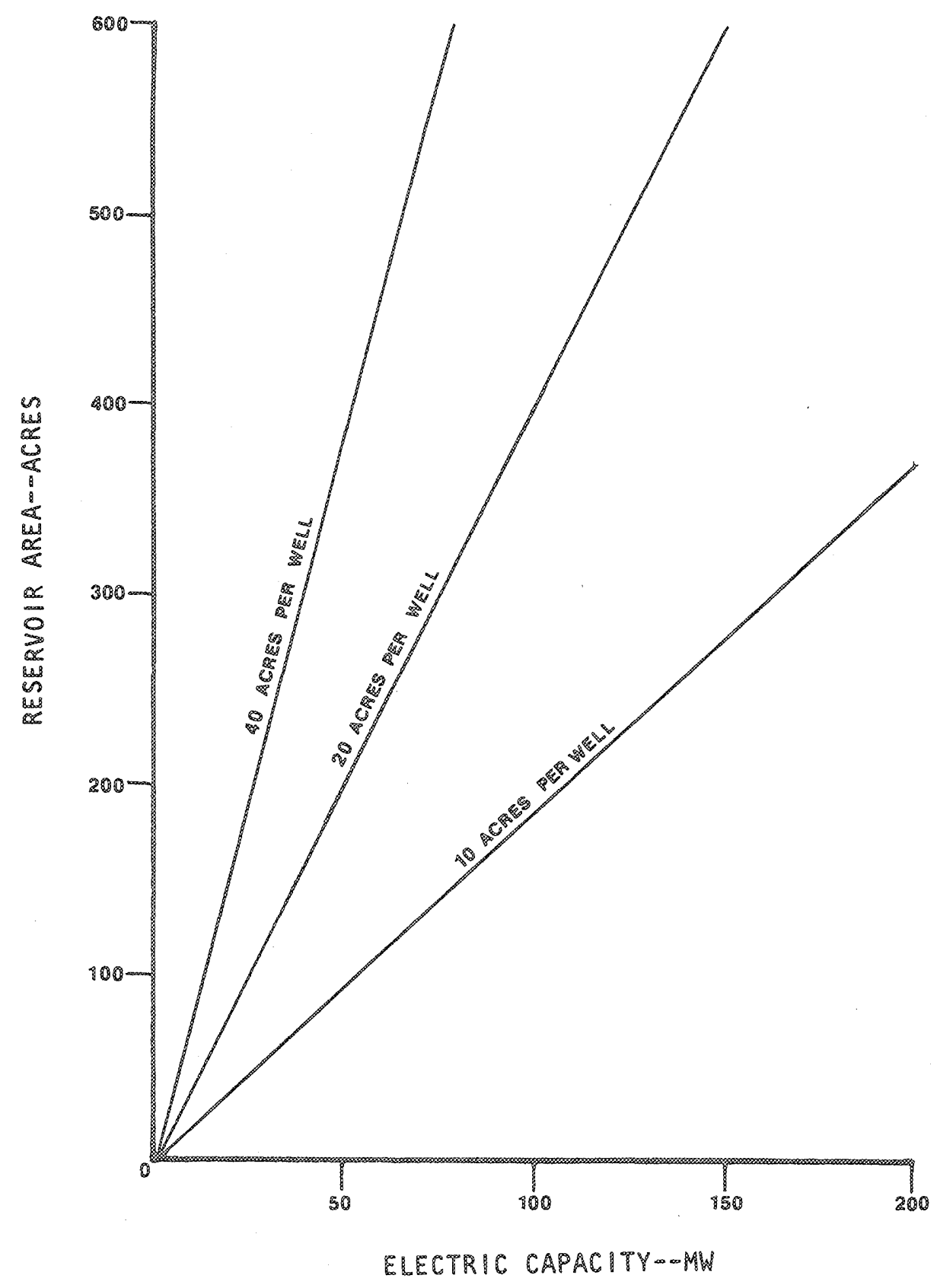


if the power plant and the wells were co-located. On the other hand, if the more conservative spacing of 40 acres/well were employed, either four well sites with the $30^{\circ}$ deviation limit, or two sites at the $45^{\circ}$ Iimit would be necessary. In the four-well-site case, four transmission pipes of length approximately $2100 \mathrm{ft}$. would be necessary providing idealized geometry could be utilized for construction.

For shallow reservoirs, however, directional drilling cannot reach as far, or gain as much advantage. For example, at 4000 feet depth only 100 acres can be reached with a $30^{\circ}$ slant limit. Still, for twenty-acre well spacing, five wells can be drilled from a single point. Instead of five one-acre drill sites, a single two-acre site might be used.

\section{Drilling Cost}

The actual cost of drilling a geothermal well is subject to so many yariables that no accurate general estimates are possible. As was noted in the introduction, Imperial Valley conditions are such that conventional oil field practice can serve as a guide (in contrast to areas of hard volcanic rock). Geothermal well drillers have suggested the following rule-of-thumb numbers for the Imperial Valley (1975 dollars). For a $3000^{\circ}$ drill hole, cased and cemented, $\$ 250,000 ; 5000^{\circ}, \$ 350,000 ; 6500^{\circ}$, over $\$ 500,000$, with costs varying roughly as the square of the depth beyond $5000^{3}$.

Factors such as transport time, set-up time, site preparation, ecc. can form a significant fraction of total well cost. Co-locating well heads can offer substantial savings to the operator. On the other hand, it must be remembered that the cost of drilling varies not simply as the depth but as the length of the bore. Reference to Table 1 shows that a maximum offset drill hole is about 10 percent longer than the depth reached. For deep holes where the square law costing relationship holds, this suggests that an offset hole will cost about 20 percent more than a vertical hole to the same depth. Thus a cost optimization for an operator 
requires a balance between drill cost, set-up cost, transmission pipe cost, land fees, and so forth.

\section{Some Environmental Factors}

As for any industrial activity, well drilling imposes environmental loads. The impacts are site-dependent. Additionally, drilling has its own peculiar aspects. Visually, a dxill rig is a prominent structure, and because it usually operates day and night, is 1ighted and therefore noticeable. The rig uses powerful pumps, engines, and hoisting machinery, and can be a local noise source. Handling of drill pipe adds to the machinery noise. Again, it should be noted that activity proceeds throughout the day.

Another environmental peculiarity of drilling is the "mud" used as drilling fluids. This is a specialized substance which is continuously pumped into the drill hole to cool the bit, stabilize the hole, counteract downhole fluid pressure, and carry the drilled rock fragments to the surface. This mud is usually kept in and circulated from a pit in the ground. After drilling is completed, the pits can be covered. Close attention should be given to the major constituents of the mud used at a hole, as well as trace elements contained in the mud, to be sure that substances harmful to the surrounding land are not ever able to escape. Sometimes even the operators are not aware of the trace element content of drilling mud. Escape could occur during drilling, but may be even more likely at a later time when the mud pit with its residual has been buried and forgotten. Sometimes operators will use movable above-ground mud tanks rather than nud pits, thereby eliminating the possible problem.

\section{Drilling in the Salton Sea}

The UCR geologists now think that a substantial reservoir exists under the Salton Sea (an underwater part of the Buttes anomoly). By inference from a recent UCR thesis, * it is surmised that a region up to

*Randa11, Walter, An Analysis of the Subsurface Structure and Stratigraphy of the Salton Sea Geothermal Anomaly, University of California, Riverside, 1974. 
five miles offshore from Obsidian Buttes may be involved. Maps of land ownership suggest that much of this is private land, but some is public domain. Maps also indicate that in this region the water is generally less than 20 feet deep. If the producing horizons are 5000 feet deep, for example, less than a one-mile strip out from shore could be tapped by slant drilling. To obtain access to the balance of the reservoir, offshore drilling will be required. Technically this should be no real problem. Oil wells are drilled off the California coast routinely in deeper water. Two methods are commonly used. One is to build a structure on pilings to support the drilling and production operations. The other is to build islands using protective rock and hydraulic fill. Access to the structure can be by trestle, causeway, or boat. Without conducting an investigation, it is not possible to state which method is preferred. Drillers will generally make a decision on economic grounds. However, environmental questions must be considered. often dredging and filling are considered more disruptive, but an environmental report should offer these comparisons on a case-by-case basis.

Some differences from oil drilling practice immediately come to mind. There is an economic limit to the distance the hot geothermal fluids can be piped, and conventional wisdom suggests that this limit is presently about one mile. Running such pipe is not a problem on causeway or trestle. A submerged pipe may be very difficult owing to themal insulation requirements, and problems with thermal expansion. However, to tap the farmout parts of the reservoir, it may be necessary to also build the power plant on an offshore structure. Power plant machinery requires fairly rigid foundations, thus massive piling or fill are probably necessary. These considerations will (adversely) affect the costs of geothermal electricity.

A great part of the area of a power plant is taken up by cooling towers. This fact, with the requirement that an expensive platform be built to support the plant, suggests that advantage may be gained by oncethrough cooling using Salton sea water. Again, this is something whose 
environmental impact will be carefully scrutinized. Transmission of the electricity to shore is no real problem. Either causeway- or trestlesupported cable can be employed, or overhead transmission with pile-supported towers is possible. Again, cost will probably be the determinant, as modified by environmental considerations.

\section{Reinjection of Geothermal Fluids in Imperial Valley}

\section{Introduction}

The concept of reinjection of produced geothermal fluids in or near the reservoirs from which they came is well accepted in geothermal technology. The intention of this brief sumary is to review several aspects of the reinjection of geothermal fluids that may be of interest to County planners. First, the purposes of reinjection will be discussed. Potential problems that may be associated with reinjection practice are mentioned. The methods of implementation for the reinjection of geothermal water will then be discussed in terms of well operation, well location and well construction. Finally, sources of injection fluids, aside from the geothermal fluids themselves, will be reviewed.

\section{Purpose of Reinjection}

In the many cases, the primary purpose of reinjection is to dispose of waters which have no further use and which would be detrimental to the surface environment. Not only in geothermal areas, but in many petroleum producing areas, reinjection is practiced. For example, some oil fields produce several barrels of salty brines for each barrel of oil produced. This water must be disposed of; moreover, by reinjecting into the original reservoir, it sometimes serves to maintain the reservoir pressure, thus enhancing oil recovery. At Wairakei in New Zealand the waters are of such quanticy and quality that they are disposed of in a nearby river; this may not often be the case. At Acuachapan in EI Salvador it was thought necessary to build a lengthy canal to the sea 
from the geothermal field for the disposition of the produced water. Reinjection is presently being considered at that site as an alternate means of disposal. At Cerro Prieto the produced waters flow to an evaporation pond and eventually some may reach the Gulf of California through drainage ditches. In the Imperial Valley, however, it is expected that no means of surface water disposal will be permitted.

The second purpose for the reinjection of geothermal fluids is to prevent subsidence of the overlying land surface. When the waters are withdrawn from the reservoirs, it is possible for the structures of the reservoix to compress, thus permitting the overlying surface to subside. This too is considered to be impermissible in the irrigated portions of the Imperial Valley. By reinjecting the waters at approximately the same rate as they are produced, it is believed that the compression of the producing formations may be prevented.

A third important reason for reinjecting the fluids is to maintain the longevity of production of the geothermal reservoir. The recharge time of a geothermal reservoix in terms of both water and heat is considered to be long compared to production time; that is, the reservoirs will deplete as they are produced. If one calculates the amount of heat present in the water and in the rock in the reservoir, it is found generally that five or more times the heat is found in the rock as in the fluid. If one withdraws the fluid without reinjection, at the time the waters are exhausted, there is still a substantial reservoir of heat left in the dried rocks. If, however, the cooled geothermal brines, after they are processed in a power plant or otherwise, are returned to the reservoir by reinjection, they may be reheated by the rocks and produced again. Gradually, of course, the reservoir will cool; however, the total production of the reservoir is substantially enhanced and most reservoir engineers recommend the practice of reinjection for this reason. Opinion is apparently uniform, at this time, that reinjection will be necessary in the geothermal fields of the Imperial Valley. 
Problems can arise, however, through reinjection practice. One potential problem is that of induced seismicity. It is known that in some areas (not geothermal areas) where injection of fluids has been practiced, that small seismic events are apparently stimulated by the introduction of fluids into the deep rock. There is apparenty no evidence at this time that reinjection will have that result in the Imperial Valley where a substantial level of seismicity already exists.

A second potential problem exists and will be of great concern to field developers. This is the problem of the reservoir being cooled by the introduction of the injected waters. If the entire reservoir begins to cool quickly as a consequence of reinjection, it is probably an indication that the reservoir was not very large in the first place. A different possibility is that the waters injected in one location will flow quickly toward the producing wells thus cooling their flow. This well interference problem could take place if the reinjected fluids were put in at the same depth and in the same general location as the producing areas in the geothermal field. The question of proper location of reinjection wells has been a subject of research in reservoir engineering, and the question will only be adequately answered when more complete reservoir information is available. That information generally becomes available after numerous wells are drilled in the fields and flow takes place.

It has been hypothesized that geothermal fields may operate as convection cells. There is a deep source of heat, which is transferred by conduction from the deepest layers into the geothermal reservoir itself. This heats the geothermal waters, which rise in a column above the heat source. The waters are gradually cooled by conduction as they move upward and outward, and then because they are cooled, sink again slowly into the depths where they are reheated. If this model is correct, it would seem that injection of fluids into the outer periphery, while producing fluids from the central core area of the cell, would insure 
that reinjected waters do not cool the produced flow and that the various objectives of reinjection are met. If a reinjection well were placed too close to the producing wells, in the middle of the cell, then one might imagine that cooling of the production formation would take place with a decrease in reservoir productivity. On the other hand, if reinjection takes place too far from the producing areas, so as to be outside the zone of circulation, only the waste disposal function would have been accomplished by reinjection, and the reinjected fluids would not recharge the reservoir either to enhance its longevity or to prevent subsidence. Thus, the correct location for reinjection wells must be determined by the reservoir engineers and the geologists on a case-by-case basis.

\section{Implementation of Reinjection}

To date, reinjection as practiced in the Imperial Valley has been a relatively straightforward operation. Reinjection wells resemble production wells in most ways; in some cases, a production well of lesser quality has been used as a reinjection well for nearby producers. It has sometimes been found necessary to apply pressure to the reinjection Fluids at the wellhead in order to force them down the well and into the formation. It is often found, however, once the cool waters begin to flow down the casing, that their greater density, as compared to the warmer water surrounding the casing, provides a pressure differential sufficient to maintain flow; essentially the reinjected waters are poured down the hole as into a vacuum.

The question still remains as to the effects of the dissolved minerals in the geothermal brine on the receiving formations. The thought is that possibly, at the cooler temperature in the reinjected bxines, the minerals may deposit in the formation, therefore plugging them. Again, only operating experience will give clear indications as to whether this is or is not a serious problem.

As previously discussed, the point of injection underground must be determined by the reservoix engineer. Having once determined what the 
pattern of reinjection points is, it would then be possible in many cases to construct wells on an offset or slant drilling basis from single wel1head points to cover a broader reinjection area. If the reinjection points are in the periphery of the field, it will often be necessary for the reinjected brines to be carried in pipelines from the power plant or other processing unit to the reinjection wellheads. Pipelines of a mile or more in length may be necessary. Previous information developed for permissible well offsets and we11 costs are applicable, because drilling methods for reinjection wells are substantially similar to those required for production wells.

\section{Sources of Reinjection Fluid}

The last point to be considered is the source of fluid for reinjection. Previous discussion has carried the implication that the reinjected fluids are geothermal waters which have been produced and processed and are now to be returned to the ground. No more would be necessary if the sole function of reinjection is wastewater disposal. If subsidence prevention and the preservation of reservoir production are also objectives, however, additional waters may be required. In some of the geothermal processes, e.g., flash steam electrical production, some of the geothermal waters are turned to steam, run through turbines, condensed and eventually evaporated away in cooling towers; thus there might be as much as 20-25 percent deficit in the volume of reinjection fluids, as compared to what was produced. In this case other waters may be required to make up the difference. Surface water, such as irrigation drainage, has been considered for such make-up purposes in the Imperial Valley. Still another possibility, unique to the Imperial Valley, is the preservation of the Salton Sea through reinjection of Salton Sea fluids to make up these water deficiencies.*

What is not known at this time is the compatibility of these surface waters with reinjection use. For example, the organic matter and

*Goldsmith, Martin, Geothermal Development and the Salton Sea, Environmental Quality Laboratory, Memo No. 17, California Institute of Technology, Pasadena, California, February 1976. 
the nutrients in the surface waters may, after injection, bring about conditions of growth which could destroy the ability of the formation to accept further recharge. These are research subjects of which little is known and where little is being accomplished. Thus, numerous aspects of the reinjection of geothermal fluids remain uncertain or unknown. The necessary knowledge will come about through research and through the beginning of operating experience. Thus great care should be taken that operating regulations are not set down, based on uncertain knowledge, which could inhibit or harm the proper development of the geothermal reservoir.

\section{Transmission Pipes}

The exploitation of geothermal resources often requires the transport of fluids between wells and processing plants. Typically, a mixture of steam and water flows from a well, and steam, or the twomphase mixture, is transported up to a mile away to an electric power plant. Residual water from the well or from the plant must then be disposed of, in all probability to a reinjection well which is apt to be at still another location.

The steam and/or water, particularly on its way from well to plant, will be at some elevated temperature and pressure. Thus, the pipeline is transporting a dangerous fluid, and the design and operation of the pipeline will be subject to industrial safety laws and codes. The role of Imperial County in the safety regulatory process may require clarification. Because the fluids may have corrosive properties which could affect the integrity of the pipes, the County should asure itself that appropriate safety codes are selected.

While the obvious source of danger is rupture of the pipe, releasing the very hot fluids, * the pipe itself can be a hazard. An uninsulated pipe can have a very high surface temperature, high enough to present a danger to humans or animals. The heat losses which accompany the use of uninsu-

* Steam or hot water, when released from high pressure, is extremely hazardous. 
lated pipe will tend to cause pipeline owners to insulate to a level which optimizes the cost of insulation against the benefit of reduced heat loss. However, such an optimization may still permit pipe surface temperatures which are hazardous. The County may wish to investigate whether existing safety codes offer adequate protection. Caution should be taken, however, to see that unrealistic standards are not applied. For example, a piece of pipe or other metal simply exposed to summer solar radiation may attain hazardous temperatures, and one cannot legislate away nature.

The trade-offs between pipeline length, thermal losses, insulation cost, and other factors are not amenable to simple analysis, and this brief treatment will not attempt to cover that problem. Some very rough estimates of the cost of transmission pipe may be of interest. Industry sources have mentioned a pipe cost (installed) of $\$ 10,000 / \mathrm{mile}$ per inch of pipe diameter. To keep pressure loss in reasonable bound, one might assume a flow velocity for steam of $100 \mathrm{ft} / \mathrm{sec}$, and for water of $10 \mathrm{ft} /$ sec. (These values are chosen only for illustration.) If a typical well produces $100,000 \mathrm{Ib} / \mathrm{hr}$ of steam and $570,000 \mathrm{lb} / \mathrm{hr}$ of liquid water at a wellhead pressure of 100 psia, the water pipe will be of 7 in. diameter, and the steam pipe will be 15 in. diameter, assuming the flow is separated at the wellhead. Thus the steam pipe will cost $\$ 150,000 / \mathrm{mile}$, and the water pipe $\$ 70,000 /$ mile. This is for surface installation.

There is apt to be one major issue concerning the transmission pipes-that is the advisability of installing them underground. On the surface, they are generally very visible. For reasons of insulation efficiency, a bright shiny surface (of low emissivity) is preferred. In the Geysers area a subdued surface color is chosen to camouflage the pipes. At Geysers the rough country would make pipe burial difficult, and might pose an environmental hazard owing to the additional excavation and subsequent exosion, etc. Those drawbacks do not exist in the Imperial Valley, and there may be pressures to install the pipes below grade. 
There is no doubt that this will result in increased cost, but an examination of the literature has revealed no published quantitative estimates. The cost is at least that of excavation, which for six-foot burial might come to 3500 cubic yards/mile. Excavation alone would apm proximate $\$ 10 /$ cubic yard.

This cost is but the beginning of the cost increment for pipe burial. For many purposes, the best insulations are fibrous materials, which really rely on the trapped air in them to impede the flow of heat. With a weather cover, these insulations are cheap and effective. If buried, however, the inexpensive weather cover must be replaced by an impervious cover which will be subjected to the action of corrosive ground water. Leakage of ground water into the insulation would destroy its insulating properties. Totally waterproof insulations (e.g., closed cell foams) are available, but are less effective and more expensive.

Another problem will come about owing to the thermal expansion of the pipe. In heating from a normal temperature of $70^{\circ} \mathrm{F}$ to a steam temperature of $350^{\circ} \mathrm{F}$, for example, a steel pipe grows in length approximately 1.9 feet in a 1000-ft run. To avoid difficulties, expansion loops or expansion joints are provided. The loop or $U$ is simple, therefore cheap and reliable. A buried pipe would require above-ground loops, or more expensive and less reliable expansion joints.

The protection of underground pipes from corrosion is always difficult, and is particularly so in a damp soil (as is likely in agricultural areas). Pipe burial can therefore be hazardous in two ways. First, the pipe is more subject to external corrosion and subsequent failure. External or internal corrosion (geothermal fluids tend to be highly corrosive) lead to pipe leakage. Above ground, the leakage is noticeable and can be quickly corrected. Below ground, the leakage will persist until substantial volumes of earth are saturated and the leak is detected. By that time substantial contamination will have resulted. Another hazard will be created if the initial small corroded area grows undetected, 
until a major pipe failure occurs. Thus pipe burial may present a substantial environmental hazard.

A means of avoiding these classes of problems is to install the pipe in a trench that is left open. The walls of the trench must be stabilized against collapse, and a cover would be necessary for safety. Provision for water drainage would be necessary. (The County of Imperial will have to supply the appropriate code requirements for such construction, and estimate the cost involved.) In this case the substantially increased costs of pipe construction must be weighed against the advantage (if any) of having the pipe hidden from view.

\section{$V \quad$ Power Plant Characteristics}

\section{Introduction}

Several classes of electric generating plant have been proposed for exploitation of geothermal resources of the hot water type. While total flow machines and other advanced concepts offer considerable promise, a plant being planned today can include only more established technology. The only type of equipment presently in commercial service, as contrasted to small experimental units, utilizes steam flashed from the geothermal water. This is the operating mode at Wairakei, Ahuachapan, Cerro Prieto, and several locations in Japan. However, substantial engineering opinion holds that "binary" plants, using an organic working fluid, are within the technical state-of-the-art. A number of analyses have indicated that binary plants offer a considerable performance advantage over flash steam plants, particularly for waters of medium temperature. (Some have defined medium temperature to be above $150^{\circ} \mathrm{C}$, whereas $250^{\circ} \mathrm{C}$ is considered to be high temperature.) Analysis published by the Environmental Quality Laboratory* indicates that flash steam systems

\footnotetext{
*Elliott, David G., "Comparison of Brine Production Methods and Conversion Processes for Geothermal Electric Power Generation, "Environmental Quality Laboxatory Report No. 10, California Institute of Technology, Pasadena, California, July 1975.
} 
offer superior performance for both high and medium temperatures. Even if so, other conditions such as high levels of noncondensible gases in the geothermal well flow may bring about a preference for binary cycles. Questions of engineering design and performance are not central to the Imperial County project. However, the consequences of the choice between generating systems are clearly within the srope of work.

\section{Existing and Proposed Plants}

It is not within the resources of the present activity to create alternative design and cost studies of representative plant configurations. Fortunately, a number of actual plant designs exist, and preliminary designs exist for proposed plants. This section is a brief review of several of these existing or proposed configurations.

Actual designs and construction costs are available for the flash plants at Cerro Prieto and Ahuachapan. These actual generating plants differ little from the dry steam plants at the Geysers. Of course, the wellhead separators and water disposal conveyances are not necessary at the Geysers, but once the steam is in the plants, the process is basically the same.

At the Geysers, Unit No. 13 is planned for $135 \mathrm{MW}$, and is estimated to cost $\$ 20,217,000$. This does not include steam wells or steam piping from well to plant. The flat pad portion of the site occupies five acres. The turbine building is the largest conventional building, $173 \times 83$ feet. The largest structure is the cooling tower, which occupies $360 \times 71$ feet. The cooling towers require $189 \mathrm{ft}^{2} / \mathrm{MW}$ in area. The cost per unit capacity is $\$ 150 / \mathrm{KW}$. The values were taken from the Environmental Data Statement for Unit No. $13 . *$ It is interesting to compare these numbers to other configurations. At Cerro Prieto, the present 75 NW plant is being expanded to $150 \mathrm{MW}$, and will then occupy 10.8 acres, exclusive of sub-

\footnotetext{
* Subsequent information indicates that the cost estimate for Unit No. 13 has substantially increased, to $\$ 240 / \mathrm{KW}$. The 1975 cost estimate for Unit No. 14 (110 MW) is $\$ 24,970,000$, or $227 / \mathrm{KW}$; PG\&E expects additional cost escalation of 12 percent (CPUC application).
} 
station. Paredes* has given the cost of the whole complex-wells, plants, and transmission-to be $\$ 19,824,000$ for the first $75 \mathrm{MW}$, or $\$ 264 / \mathrm{KW}$. The plant itself is reported at $\$ 125 / \mathrm{KW}$ if indirect costs are allocated in the same ratio as direct costs. The cooling towers occupy $273 \mathrm{ft} / \mathrm{MW}$. Inlet steam is delivered at $75 \mathrm{psi}$ and $320^{\circ} \mathrm{F}$. The steam rate is approximately $17.1 \mathrm{lbs} / \mathrm{KW}-\mathrm{hr}$, and discharges at 3.5 inches $\mathrm{Hg}$. This can be contrasted to a typical Geysers plant, where steam is admitted at 100 psi and $355^{\circ} \mathrm{F}$, with 4 inches $\mathrm{Hg}$ exhaust; the steam rate is $16.51 \mathrm{bs} / \mathrm{KW}-\mathrm{hr}$. While the steam rates for the two plants are similar, the Cerro Prieto plant apparently requires more cooling tower area, possibly owing to the hotter climate.

At Ahuachapan, in EI Salvador, the first $30 \mathrm{MW}$ unit of a planned $90 \mathrm{MW}$ complex has been completed. The entire plant, exclusive of substation, will occupy 5.1 acres. The cooling towers, in the preliminary plans, require $269 \mathrm{ft}^{2} / \mathrm{MW}$. The design turbine entry conditions are not known to the author, but are believed to be about the same as at Cerro Prieto, in spite of the fact that the reservoir is not as hot. No upto-date costs appear in the literature, but private communication indicates that capital costs are $\$ 533 / \mathrm{KW}$ for the first unit, with wells and pipes (but without brine disposal), and $\$ 600 / \mathrm{KW}$ for the second $30 \mathrm{MW}$ unit with wells. The third $30 \mathrm{MW}$ unit well uses low pressure steam flashed from the water stream of the first two units. While it will, therefore, be larger and more expensive, it involves no well cost. That unit is presently projected to cost $\$ 600 / \mathrm{KW}$.

A11 of the New Zealand units were built some years ago when costs were far lower than today. Moreover, they do not employ cooling towers, but do involve a more complex field plumbing system than at the other locations mentioned, owing to the incorporation of high and medium pressure wells and turbines.

\footnotetext{
*Speech, E1 Centro, California, October 17, 1973 (translated by Dept. of Water Resources).
} 
For binary plants we have no actual construction experience. Three design studies are available, however, performed for ERDA by Bechtel, * TRW, $* *$ and the Idaho National Engineering Laboratory.***

The Bechtel design is for a plant described as having 10 MW net output. This is not quite accurate, however, as the binary cycle design requires the wells to be pumped, and the pumping power must be deducted from the $10 \mathrm{MW}$. Other studies indicate that 10 to 25 percent of the power is necessary for that function, depending on assumed well conditions. The Bechtel design calls for wet cooling towers $\left(970 \mathrm{ft}^{2} / \mathrm{MW}\right)$ and has a turbine building of $80 \times 65$ feet. The control building is $80 \times 35$ feet. The power plant, without an accompanying laboratory facility, occupies 2.7 acres. However, to insure an uninterrupted supply of canal cooling water (the canals are assumed to be shut down three days each month) a storage pond of 3.3 acres was included. The power plant, without wells or field equipment, was estimated to cost $\$ 16.2$ million, or $\$ 1,620 / \mathrm{KW}$. The plant was designed for the Heber Field.

TRW designed a plant for the East Mesa field. Without an accompanying laboratory, the plant occupies 6.5 acres and produces 6.3 MW net. The well pumping requires $1.7 \mathrm{MW}$, thus the comparable figure to the Bechtel plant is $8 \mathrm{MW}$. TRW postulated the use of dry cooling towers, which are costly, inefficient, and space consuming, but require no cooling water. They occupy $110 \times 250$ feet $\left(3,457 \mathrm{ft}^{2} / \mathrm{MW}\right)$ and the control building is $60 \times 60$ feet. The turbine building is $80 \times 50$ feet (equivalent). With cost escalation included, the plant cost is $\$ 14,978,000$, without wells or field equipment.

*Electric Power Generation Using Geothermal Brine Resources, Bechtel Corp., San Francisco, May 1975.

**Experimental Geothermal Research Facilities Study, TRW, December 1974. ***Conceptual Design and Cost Evaluation of Organic Rankine Cycle Electric Generating Plant Powered by Medium Temperature Geothermal Water, Idaho National Engineering Laboratory, December 1975. 
The Idaho National Engineering Laboratory has designed a binary plant for medium temperature application. The plant has a net output of $10 \mathrm{MW}$, but $1.43 \mathrm{MW}$ is supplied to the well pumps for an $11.4 \mathrm{MW}$ total. Their cost estimate is $\$ 10,661,000+16$ percent contingency for a total of $\$ 12,367,000$, not including wells or field equipment. INEL has also designed a 50 MW plant (57.2 MW total output) which is estimated to cost $\$ 37,076,000$.

\section{Comparison of Plant Costs}

INEL has tried to develop scaling relationships for plant cost and size. All components do not scale the same way, but overall they report a relationship where cost varies as net power output to the power 0.7 . If we accept this scaling relationship, it is possible to normalize the various plant cost estimates to some standard size. For illustration let us select the value of $100 \mathrm{MW}$. If this is done, the following unit costs are obtained.

$\begin{array}{lc}\text { Geysers (based on Unit 14) } & \$ 243 / \mathrm{KW} \\ \text { Geysers (based on Unit 13) } & 263 \\ \text { Cerro Prieto } & 115 \\ \text { Ahuachapan (with we11 costs) } & 415 \\ \text { Bechtel (without well pumping power) } & 810 \\ \text { TRW } & 878 \\ \text { INEL } & \end{array}$

Unless otherwise noted, the cost of wells, pipes, separators, and other field equipment is excluded. Moreover, these plants are designed for diffexing reservoir conditions. The effect of reservoir temperature will be considered in a later section.

The values for the Geysers represents units not yet under construc tion, thus can be considered current estimates. On the other hand, Cerro Prieto was constructed in the early seventies, and today would cost significantly more. Ahuachapan has encountered many poor wells, and much money has been spent in exploratory drilling. We do not have separate numbers for wells and plant. One is struck by the high esti- 
mates for the binary plants. It is not astonishing that they are much higher than stean plant costs, however. Advocates of binary systems have asserted, not without reason, that organic fluid turbines should be much more compact, and thus much cheaper than steam turbines of equivalent capacity. By implication, then, they have suggested that power plant costs will be low. However, a cost breakout of plant elements (such as given in the INEL report) shows that the turbine and alternator are only 10 percent of plant cost. The binary plant also requires a whole variety of heat exchangers of large capacity and good performance, however, and this equipment, plus the elaborate plumbing, makes for a costly, complex installation, which incidentally requires considerably more area than the flash steam plant.

Considering our lack of actual experience with flash steam or binary plants in the USA, all of the estimates should be viewed with caution. However, the flash steam values are based on real construction, albeit in other lands, while the binary plant estimates have not had the solidifying benefit of encounter with construction reality. Expexience would indicate that initial installations, at least, will exceed present estimates when they are actually built. At the present time, at least two organizations are preparing design and cost estimates for geothermal power plants intended for Imperial Valley conditions. The Ben Holt Co. is under contract to EPRI and the Bechtel Corp. is under contract to ERDA. Results are not yet available.

The only conclusions that can be drawn from the above data (and these are tentative conclusions indeed) are that flash steam plants are less expensive and less land-intensive than binary plants. As the cooling requirements increase with diminishing plant efficiency, the lower temperature reservoirs will require larger power plants for the same output as compared to high temperature reservoirs. If it turns out that binary plants are necessary for medium temperature reservoirs, then the area and capital requirements for the plants may be substantially larger than 
for flash steam plants. In the view of this author, the necessity for binary plants is still undetermined.

To round out the cost picture, some estimate of the cost of the well field is necessary. Here many uncertainties still exist. For example, the cost of land or lease acquisition is subject to large and unpredictable variations. Moreover, some geothermal areas have already had a considerable degree of exploration (particularly in the Imperial Valley). In those cases, generalized estimates for the costs attributable to exploration either are sunk or do not apply. It is not hard to get a rough (rough ${ }^{2}$ ) figure for field investment. If one can average $5 \mathrm{MW}$ per production well, spending $\$ 400,000$ per well, the well cost is $\$ 80 / K W$. To this add 50 percent for reinjection wells. Well head equipment, separators, mufflers, etc., must be added, together with steam and water transmission pipes (which might average $\$ 100,000-200,000$ per mile). Altogether field investment is apt to total \$150-200/KW, at least for high temperature reservoirs.* For medium temperature reservoirs, the cost will be higher for several reasonsmbecause the temperature is lower, the efficiency of conversion is lower, requiring higher mass flows. If self-flowing, the well flow rate will be less-to increase the flow, pumping may be required.

A factor of two increase in cost is not unlikely, and in fact the INEL has estimated field investment at $\$ 530 / \mathrm{KW}$, and they estimate this is relatively constant, regardless of plant size (as between 10 and 50 MW)。

\section{Power Plant Size Selection}

The question is posed as to the appropriate size for geothermal electric power plants in the Imperial Valley. This is a complex problem, involving cost scaling with size, equipment reliability, and many more factors which enter into the selection of appropriate power level for

*Cerro Prieto, constructed five years ago, cost $\$ 102 / \mathrm{KW}$. 
any class of generating plant. Geothermal plants are subject to the additional vaxiables of field size and production, as well as the physical characteristics of the produced fluid.

One key constraint on geothermal plant size is the distance between the wells and the plant; if the distance is too great, pipeline cost and power losses become excessive. Yet for proper management of the reservoir, the power production per unit area must be limited. These limitations are not yet known for the Imperial Valley. At the Geyser field, for example, wells are spaced on 40 acres each (approximately) with the intention of in-filling wells as productivity of the original vells falls off. Data* show that total field productivity would be reduced if closer (e.g., 5-acre) spacing were utilized. On the other hand, at Cerro Prieto the operators have chosen to operate wells on spacing of approximately 10 acres. At Ahuachapan, wells are spaced at about 20 acres, but not all the wells have been successful. All Imperial Valley operators seem to agree that appropriate well spacing is as yet unknown. For analysis, therefore, a range of values must be selected.

The calculations of Elliott** indicate that one might expect to produce 2 to $3 \mathrm{MW}$ per well from $150^{\circ} \mathrm{C}$ reservoirs, and upward to $10 \mathrm{MW}$ or more for a temperature of $250^{\circ} \mathrm{C}$. Again, a range of values must be considered.

Another factor is the permissible length of transmission pipe. Distances of from one-half to one mile have been considered acceptable in different locations. For one-half mile maximum pipe lengths, 500 acres can feed one power plant. At 40-acre spacing, if twelve wells

*Budd, Chester F., Jr., "Steam Production at the Geysers Geothermal Field," Geothermal Energy, ed. by Kruger and Otte, Stanford Univ. Press, 1973.

**Elliott, David G., Comparison of Brine Production Methods and Conversion Processes for Geothermal Electric Power Generation, EQL Report No. 10, California Institute of Technology, Pasadena, July 1975. 
are installed with only three MW/well, the plant power might only be 35 MW. At 10-acre spacing, however, and $10 \mathrm{MW}$ per we11, a $500 \mathrm{MW}$ plant is possible. With these sort of values as bounds, it is clear that no definitive conclusions can be drawn until reservoir data are in hand.

What other characteristics of geothemal power plants might limit their size? Geothermal steam plants differ from fossil-fired or nuclear steam plants in that geothermal plants are considerably less efficient, owing to the low steam temperatures. This efficiency is reflected in the steam rate (the number of pounds of steam required to generate one kilowat-hour). While a modern fossil plant might have a steam rate of under $7 \mathrm{lb} / \mathrm{kw}-\mathrm{hr}$, the Geysers plants and the Cerro Prieto plant require about $17 \mathrm{lb} / \mathrm{kw}$-hr. Steam rate may be an interesting parameter to use in comparing power plants. All the configurations being considered use condensing turbines, which exhaust at very low pressure. As the pressure on the steam is reduced, it expands to large volume. Therefore, the exit sections of the turbine are very large compared to the high pressure sections. Both cost and practicality are probably governed in great measure by the size of the exit sections.

Also, with minor variations, the cooling capacity required for a turbine is proportional to the steam rate. Thus those expensive components making up the cooling system (condensers, cooling towers, pumps, etc.) will scale in size and cost with steam rate.

The next step is to determine steam rates for plants using steam of various temperatures. The date from Elliott's study are directly useful. Unfortunately, the reference does not contain all the internal numbers generated in the calculations. However, the author has kindly supplied the necessary figures, shown in Table 2. These figures show the markedly lower performance expected at lower temperature reservoirs. Elliott ${ }^{\prime} s$ calculations also show one interesting tradeoff. For example, in the $250^{\circ} \mathrm{C}$ reservoir case, a two-stage system has a larger steam rate 
to the condenser than a one-stage system, although the total well flow requirements are less. Thus one weighs a more expensive power plant against better utilization of the well flow.

TABLE 2

Steam Rates for Two-Stage Flash Steam Geothermal Power Plants

Reservoir

Temp. ${ }^{\circ} \mathrm{C}$ $150^{\circ} \mathrm{C} \quad 200^{\circ} \mathrm{C}$

$250^{\circ} \mathrm{C}$

$300^{\circ} \mathrm{C}$

$241^{\circ} \mathrm{C}^{1}$

$250-300^{\circ} \mathrm{C}^{2}$

Turbine Inlet

Temp. ${ }^{\circ} \mathrm{C}$

$114^{\circ} \quad 146^{\circ}$

$187^{\circ}$

$218^{\circ}$

$179^{\circ}$

$160^{\circ}$

Steam Rate

$\mathrm{Ib} / \mathrm{kw}-\mathrm{hr}$

\section{5
ysers
rro Prieto}

$1_{\text {Values for Geysers }}$

${ }^{2}$ Values for Cerro Prieto

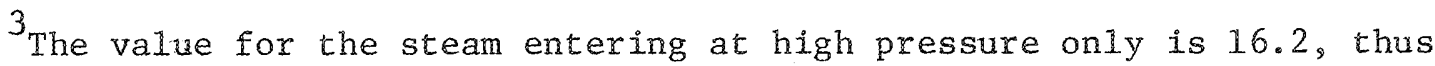
compares closely with Geysers.

It is known that modern high pressure turbines for fossil and nuclear plants are built in sizes ranging up to $1200 \mathrm{MW}$. Their steam rates are 7-8 $1 \mathrm{bs} / \mathrm{kw}-\mathrm{hr}$. For equal steam flows this would imply that turbines for $300^{\circ} \mathrm{C}$ geothermal reservoirs might range up to 500 or 600 MW. It should be realized, however, that the economy of scale realized in large power plants, particularly nuclear plants, may derive from the steam supply, not the turbine. The painful service history of the largest turbines suggests that the utilities might prefer smaller ones.

At Geysers, PG\&E has designed for as much as 135 MW from one generator. This unit uses a two-cylinder turbine, essentially two separate turbines on one shaft, driving a single generator. PG\&E has stated that not only transmission pipe length but the load capacity of the access road system limits them to units of this approximate size. 
It seems unlikely that geothermal units of over $200 \mathrm{MW} w i 11$ be installed in the forseeable future, and that size might be used only on the hottest of reservoirs. Units of approximately $100 \mathrm{NW}$ maximum are more likely. If steam flow is truly the significant parameter, the maximum plant size at cooler reservoirs (under $200^{\circ} \mathrm{C}$ ) is apt to be $100 \mathrm{MW}$, with 50 MW units being more likely. Note that present ERDA studies of commercial plants are directed toward 50 MW units.

\section{Cost Scaling with Reservoir Temperature}

The power plant costs developed by Bloomster* show the breakout between items. The turbine and generator, lumped together, cost about one third of the total. Let us assume 20 percent is turbine and 13 percent is generator. Then the electrical equipment (switchyard, generator, control equipment) appears to amount to about 30 percent of the cotal; thus 70 percent is steam-associated. Let us assume the cost of steam equipment scales with steam rate. It is unlikely that the costs scale directly as the steam rate, but one could use that as an initial assumption. If one begins from the known cost at Geysers, for example, and scales costs for less efficient plants, the linear assumption should be conservative.

In the previous cost estimating work, the normalized (to $100 \mathrm{MW}$ ) cost at Geysers (Unit 14) was $\$ 243 / \mathrm{kw}$. If we take this to represent a flash steam plant and use the above linear steam rate scaling assumption, together with the estimate of 70 percent of plant cost being steam rateassociated, the following values result.

\section{TABLE 3}

Estimated Cost/kw of Two-Stage Blash

Geothermal Power Plants

(Normalized to $100 \mathrm{MW}$ )

$\begin{array}{cc}\text { Reservoir Temp. } & \frac{\text { Cost }}{150^{\circ} \mathrm{C}} \\ 200 & \$ 459 / \mathrm{kw} \\ 250 & 318 \\ 300 & 272 \\ & 235\end{array}$

*Bloomster, C. H. and C.A. Knutson, "The Economics of Geothermal Electricity Generation from Hydrothermal Resources," Battelle Pacific Northwest Laboratories BNWL-1989, UC-13. 
These values can be compared to those estimates previously reported for binary plants. For example, the Bechtel estimate (normalized) for the Heber field is $\$ 810 / \mathrm{kw}$. The reservoir temperature was assumed to be $193^{\circ}$. Without doubt, scaling relations for the cost of binary plants will reflect a similar dependence on reservoir temperature.

It is thus clear that the cost of developing power from the cooler reservoirs will be substantially higher than at the hot reservoirs that have been utilized so far. First, one pays the cost penalty shown above for the power plant. Additionally, well cost will be substantially higher for a unit of power. Figure 12 of Elliott's report makes the point clear1y. The total available power from a well of standard configuration is very much greater at $300^{\circ} \mathrm{C}$ as compared to $150^{\circ} \mathrm{C}$.

Considering that Elliott's calculations indicate that two-stage flash steam systems deliver from 0.52 to 0.56 of available power, one could choose a value of 0.5 as typical. For Elliott's standard well, typical of Imperial Valley conditions, the following approximate electric output per well is available.

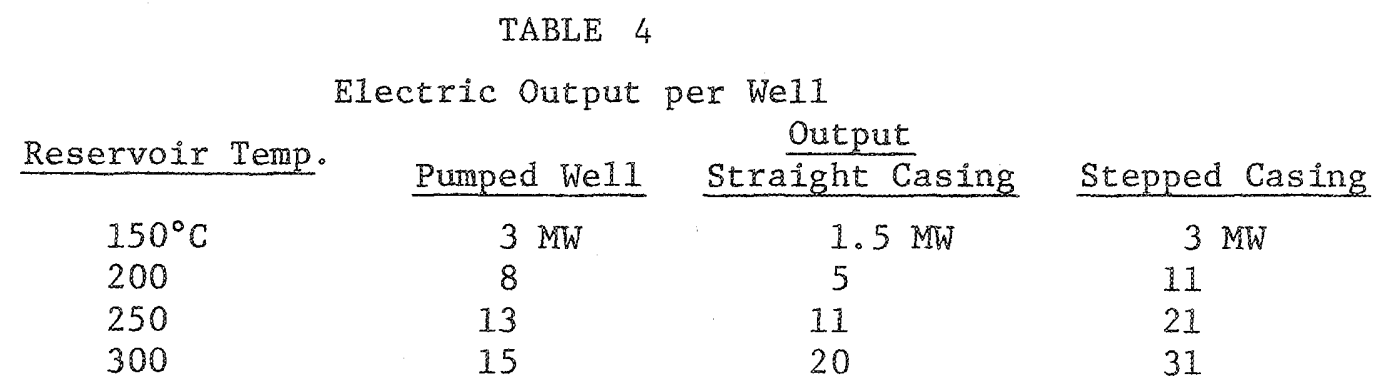

The step casing concept has not yet been thoroughly tested, so let us put those interesting figures aside. A less productive formation, as illustrated in Elliott's Figure 14, would result in lower output values. With all the uncertainties in absolute values to be found in the field, the cost implications are clear, however.

If we assume the cost of a well plus transmission pipe to be $\$ 500,000$, the values of Table 4 translate to dollars as follows: 
TABLE 5

Cost of Wells per Unit Output

$\begin{array}{ccccc}\text { Reservoir Temp. } & \frac{\text { Pumped }}{\text { Straight }} & & \text { Stepped } \\ & \$ 167 / \mathrm{kw} & & \$ 333 / \mathrm{kw} & \$ 167 / \mathrm{kW} \\ 200 & 63 & & 100 & 45 \\ 250 & 38 & 45 & 24 \\ 300 & 33 & 25 & 16\end{array}$

These numbers do not reflect exploration costs, land costs, and costs of unsuccessful wells. Thus they are too low by a substantial factor. How ever, the trend with temperature is evident. As can be seen from Tables 3 and 5 , while the costs of geothermal plants and well arrays on a $250^{\circ} \mathrm{C}$ reservoir may prove to be highly attractive, the well and power plant cost at a $150^{\circ} \mathrm{C}$ reservoir are very much greater. The other fact clearly illustrated by this analysis is the great difficulty faced by all of us in understanding and reconciling cost estimates made by various organizations for different reservoirs and using different conversion methods.

VI Cooling Requirements for Geothermal Power Plants

All power plants that convert heat to mechanical or electrical energy require a means of cooling. This is usually accomplished in one of three ways: direct transfer of heat to a body of water; direct transfer of heat to the atmosphere; evaporation of water into the atmosphere. Because geothermal resources are at a low temperature as compared to those found in ordinary steam boilers, the themodynamic efficiency of geothermal power plants is low, and their cooling requirements are much greater as compared to conventional plants.

The heat rejection from geothermal plants can be calculated from data presented in earlier sections. For example, the steam rates previously calculated for flash steam plants are as shown in Table 6.

TABLE 6

$\begin{array}{lllll}\text { Reservoir Temp. }\left({ }^{\circ} \mathrm{C}\right) & 150 & 200 & 250 & 300 \\ \text { Steam Rate } 1 \mathrm{~b} / \mathrm{kw}-\mathrm{hr} & 37.5 & 23.8 & 19.3 & 15.8\end{array}$


Steam condensing at $120^{\circ} \mathrm{F}\left(49^{\circ} \mathrm{C}\right)$, for a turbine back pressuxe of 3.5 in. $\mathrm{Hg}$ (a typical condition), releases $1025.8 \mathrm{BTU} / \mathrm{lb}$. With the steam rate, this yields the heat rejection rate.

Suppose a stream of watex from a river, lake, or ocean were used to remove this heat. A typical temperature rise through the condensers is $20^{\circ} \mathrm{F}$, say from $80^{\circ} \mathrm{F}$ to $100^{\circ} \mathrm{F}$. Then $20 \mathrm{BTU} / 1 \mathrm{~b}$ is removed by the flow. In this case $\frac{1025.8}{20}=51.3$ is the ratio of cooling flow to steam rate. For convenience in comparison, let us use annual cooling flow requirements. For a plant capacity factor of 80 percent, the steam flow is $24 \times 365 \times .80 \times$ steam rate,

or $7008 \mathrm{x}$ steam rate in $1 \mathrm{~b} / \mathrm{yr} / \mathrm{kw}$ capacity, or $7 \times 10^{6} \times$ steam rate $\frac{1 \mathrm{bs}}{\mathrm{yr}} / \mathrm{hw}$.

Thus the annual cooling flow needed is $51.3 \times 7 \times 10^{6} \times$ steam rate, or converting to acre-ft/yr,

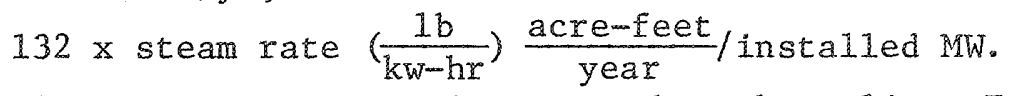

Thus, for a flash steam system using once-through cooling, Table 7 can be calculated.

\section{TABLE 7}

$\begin{array}{lrrrr}\text { Reservoir Temp. }\left({ }^{\circ} \mathrm{C}\right) & 150 & 200 & 250 & 300 \\ \text { Cooling water rate }\left(\frac{\text { acre-ft }}{\text { year }} / \text { MW }\right) & 4950 & 3140 & 2540 & 2070\end{array}$

These numbers indicate, for example, that a $100 \mathrm{MW}$ plant, having a reservoir temperature of $250^{\circ} \mathrm{C}$, will require 254,000 acre-ft/year of cooling flow. To put this in context in the Imperial Valley, this value is over half the flow of the New River. For a $1000 \mathrm{MW}$ plant operating from a $200^{\circ} \mathrm{C}$ reservoir, the entire flow of the All-American Canal would be required. The flow is not consumed, of course, but is simply heated $20^{\circ} \mathrm{F}$. It is seen that these flows are extremely large, and such a cooling system is probably impractical, even if various environmental problems could be overcome.

Most plant designers have assumed the use of evaporative cooling towers for geothermal plants in the Imperial Valley. This is the system 
used at Geysers, Cerro Prieto, etc. In existing plants the condensed steam is used as makeup water in the cooling towers, and there is therefore no requirement for supplemental cooling watex. This means, however, that there is a net withdrawal of fluid from the geothermal reservoir. If this is not permissible, then either the condensate must be reinjected, in which case supplemental cooling water must be supplied, or the supplemental water will be required for reinjection. In either case, the supm plemental water requirements will approximate the steam rate. That is, for every pound of steam condensed, about one pound must be evaporated in the cooling tower. (This varies according to the amount of condensation that occurs in the turbine and the air temperature rise in the cooling tower.) Thus the following table for supplemental water requirements can be calculated.

\section{TABLE 8}

$\begin{array}{lrrrr}\text { Reservoir Temp. }\left(C^{\circ}\right) & 150 & 200 & 250 & 300 \\ \text { Supplemental water }\left(\frac{\text { acre-ft }}{\text { year-MW }}\right) & 97 & 61 & 50 & 41\end{array}$

Therefore, a $100 \mathrm{MW}$ plant, on a $200^{\circ} \mathrm{C}$ reservoir, will require about 6100 acre-feet/year of cooling water for its towers if its condensate is rem injected. Actually, a somewhat (10-20\%) greater supply may be needed to account for blowdown (required for tower water quality control). Be reminded, however, that if it is required to reinject only the separated brine, which may amount to 80 percent of the well flow, that the flash steam plant will have little or no requirement for supplemental cooling water, and any tower blowdown can be reinjected with the brine flow.

The situation is different in the case of the non-flashing binary cycle plant. There an external supply of cooling water will be required. The heat rejection rate for binary plants can be obtained from the EQL report of Elliott. In Figures 31 and 32 he shows the power output per unit heat rejection for various cycles at reservoix temperatures of $150^{\circ} \mathrm{C}$ and $300^{\circ} \mathrm{C}$. From Figure 31 the ratio for two-stage flash systems is 0.095 , and for binary systems it is 0.06 . Thus a binary plant requires 
$\left(150^{\circ} \mathrm{C}\right.$ reservoix temperature)

$$
\frac{0.095}{0.06}=1.58
$$

the amount of cooling as a flash plant. At $300^{\circ} \mathrm{C}$, Figure 32 shows the ratio to be

$$
\frac{0.22}{0.165}=1.33 \text {. }
$$

If we simply interpolate Iinearly between these two values, the following table is constructed:

$\begin{array}{cc}\text { Reservoir Temp. } & \text { Heat Rejection Ratio }\left(\frac{\text { Binary }}{\text { Flash }}\right) \\ 150 & 1.58 \\ 200 & 1.49 \\ 250 & 1.41 \\ 300 & 1.33\end{array}$

Using these ratios, a table of cooling water requirements can be calculated for binary plants, using Tables 7 and 8 .

TABLE 9

Cooling Water Requirements for Binary Plants

$\begin{array}{lrrrr}\text { Reservoir Temp. }\left({ }^{\circ} \mathrm{C}\right) & 150 & 200 & 250 & 300 \\ \text { Once-through }\left(\frac{\text { acre-ft }}{\text { year-MW }}\right) & 7800 & 4670 & 3580 & 2750 \\ \text { Evaporative Tower* }\left(\frac{\text { acre-ft }}{\text { year-MW }}\right) & 167 & 101 & 77 & 59.5\end{array}$

*Does not account for required blow-down

The water requirements are fairly substantial. Unless the power plant were located directly next to the New or Alamo River, it is doubtful that once-through cooling would prove practical. The evaporative makeup water requirements for $1000 \mathrm{MW}$ of binary plant capacity will come to above 75,000 acre-feet/year, even for a reservoir temperature as at Niland. For the cooler reservoirs, such as Heber, over 100,000 acre-feet/year would be needed. In subsequent sections we will consider possible sources for cooling water.

One other possibility for cooling remains. That is the use of aircooled, or dry, towers. As in an auto radiator, the heat is transferred directly to the air. (In a wet tower, a small amount of heat is trans- 
ferred to the air, but most of the heat is given up to the evaporating water.) Dry towers suffer from two substantial drawbacks. First, the heat transfer mechanism is less efficient, thus the towers must have a greater heat transfer surface, and are therefore substantially more expensive.

The second drawback is that the dry tower, in rejecting heat to the air, "sees" the dry bulb temperature. A wet tower "sees" the wet buIb temperature, which is always lower. In a hot, arid region, this temperature difference can be very significant. In the Imperial Valley, temperatures of over $100^{\circ} \mathrm{F}$ are reached over 100 days each year, but the relative hmidity might typically be 30 percent. In the case of $100^{\circ} \mathrm{F}$ dry bulb temperature and 30 percent R.H., the wet bulb temperature is only $74^{\circ} \mathrm{F}$. At $120^{\circ} \mathrm{F}$ dry bulb, the wet bulb would be approximately $90^{\circ} \mathrm{F}$. Thus the wet tower is able to achieve much lower heat rejection (condensing) temperatures, which has great impact on thermodynamic efficiency. This impact is greater for cycles having smaller temperature differentials between the hot and cold side, e.g., geothermal power plants would be more affected than coal-fired plants. It is beyond the scope of this work to make detailed estimates of the efficiency loss of vaxious geother mal plants, and no serious consideration is presently being given to their use.

A concept called wet/dry cooling towers is currently being explored for power plant applications. In these devices, there is both a dry and wet section. The use of the dry section reduces water consumption and inhibits plume formation; the wet section maintains plant efficiency in warm conditions. Should water conservation prove a significant goal in the operation of geothermal power plants, the use of wet/dry towers should be investigated. It has been estimated that for some fossil or nuclear plants, cooling water requirements might be reduced by 50 percent or more. on the other hand, their use involves cost and performance penalties. 
The previous section has delineated the cooling water requirements for geothermal power plants. This discussion will review the possible sources of cooling water if it should be required. No substantial sources of surface or shallow ground water exist naturally in the Imperial Valley. The water base for the economy is the Colorado River, and the water is transported to the Valley by the Al1-American Canal. The amount of water diverted to the Imperial Irrigation District varies from year to year, but a quantity of 2.8 million acre-feet/year is typical. This water is used for municipal and agricultural purposes. Some is lost to evaporation and leakage from the open canal system. Of that applied to the land, perhaps two thirds is consumed by evapo-transpiration, and one third is drained away as waste. This wastewater production, a significant aspect of the hydrologic cycle in the Imperial Valley, is necessary to keep the salt content of the Colorado River water from poisoning the land. The waste does not simply percolate into deeper layers, owing to the low permeability of the subsoils. Rather it is removed by tile drains and a canal system. Again, while values vary from time to time, the Imperial Valley includes about 450,000 irrigated areas. Thus, over six feet of total water per year is required for irrigated 1and. Open pan evaporation data indicate that 5.8 feet are lost to evaporation from exposed water surfaces.

The best source of quality cooling water that one might consider is the fresh irrigation water. It has previously been shown that oncethrough cooling is not a realistic option for any but the smallest demonstration plant in the Imperial Valley. Even evaporation towers would require perhaps 6000 acre-feet per year to serve a 100 MW plant. Thus one would have to relinquish 1000 acres of agriculture for a single 100 MW power plant. The advisability of such an exchange goes far beyond the technical aspects. For example, one would be trading $\$ 12$ million 
revenue from electricity (at $20 \mathrm{mills} / \mathrm{kw}$-hr ) against an estimated $\$ 1$ million in farm income. However, it is probably not necessary to make such a choice, as other sources of cooling water may be available. A relatively small amount of ground water might be available in particular spots in the Valley. Some of these spots are know to be fed by seepage from the irrigation canal. This water is limited in quantity, and is often of quality sufficient to be used for agriculture. If the canals were lined someday, the source of the water would disappear.

The most 1ikely major source of water is irrigation drainage. An elaborate system of field drains accumulates the water and finally deposits most into the New or Alamo Rivers. These in turn flow into the Salton Sea. The water has no further value for irrigation. It has a solids content of about $3000 \mathrm{ppm}$, plus generous loads of nitrates, phosphates, and organic substances. A major question is the level of treatment requixed before the water can be used in cooling cowers, which will be discussed in the next section. The total amounts of water flowing in these two rivers is very substantial. In a typical year, the New River might flow 420,000 acre-feet and the Alamo River might flow 650,000 acre-feet. Clearly the potential exists for cooling a total plant capacity greatly in excess of $10,000 \mathrm{MW}$. Utilizing the flow is not entirely straightforward, however. First, any water used would have to be transported to the power plant. Considering the advanced state of development of the present surface water transportation system, it is likely that pressure pipe would be necessary to move the cooling water to avoid interference with existing activities.

Another more difficult problem might be the variation of flow in the two rivers. Most natural rivers vary in their flow according to season, and these variations can be very great. Even though the New and Alamo Rivers are drains, essentially unaffected by rainfall, the changing requirements for irrigation water through the year cause substantial daily and monthly variations in flow. Variations from year to year are less significant. 
This is illustrated in Figures 4 and 5 , where the flow rates in the New and Alamo Rivers are shown over a three-year period, on a monthly basis. The range of rates over each month is shown by the vertical 1 ines. The plotted curves show the variation in the monthly means. Clearly, a substantial seasonal variation in flow exists.

As long as withdrawals are less than the minimum flow in the river, only diversion structures would be needed. If a withdrawal rate greater than this is expected, some water storage will be required to average out the variable flows. In the three years of data depicted, the minimum flow in the New River was $429 \mathrm{cfs}$, or an annual equivalent of 310,000 acre-feet. The Alamo River flowed a minimum of $435 \mathrm{cfs}$, or 314,000 acrefeet annual equivalent. Thus, this amount of flow could be diverted without the necessity for storage capacity. If storage were added to the system, the "guaranteed" supply would be increased, as the storage could be drawn upon during periods of lower flow. The amount of storage required for flow equilization must be calculated using known flow data, projected into the future. If one only wished to compensate for the days of lowest flow in the month of minimum flows, possibly storage of only a few days flow requirements for the power plant may be necessary. If, on the other hand, one wished to balance flows from month to month, perhaps one or two months worth of water requirements would be necessary.

If a typical $1000 \mathrm{MW}$ geothermal power plant complex requires 60,000 acre-feet/year, the New and Alamo Rivers are capable of supporting over 5000 MW capacity each, without storage capacity. Clearly, a great deal of geothermal development is possible before major water storage would be required.

The use of cooling water from the Salton Sea has been considered in EQL Memo No. 17.* Two modes are possible, one using the water for once-

*Goldsmith, Martin, "Geothermal Deveiopment and the Salton Sea," Environmental Quality Laboratory Memorandum No. 17, California Institute of Technology, Pasadena, California, February 1976. 
PIGURE 4. MONTKLY FLOW DATA-NEW RTVER

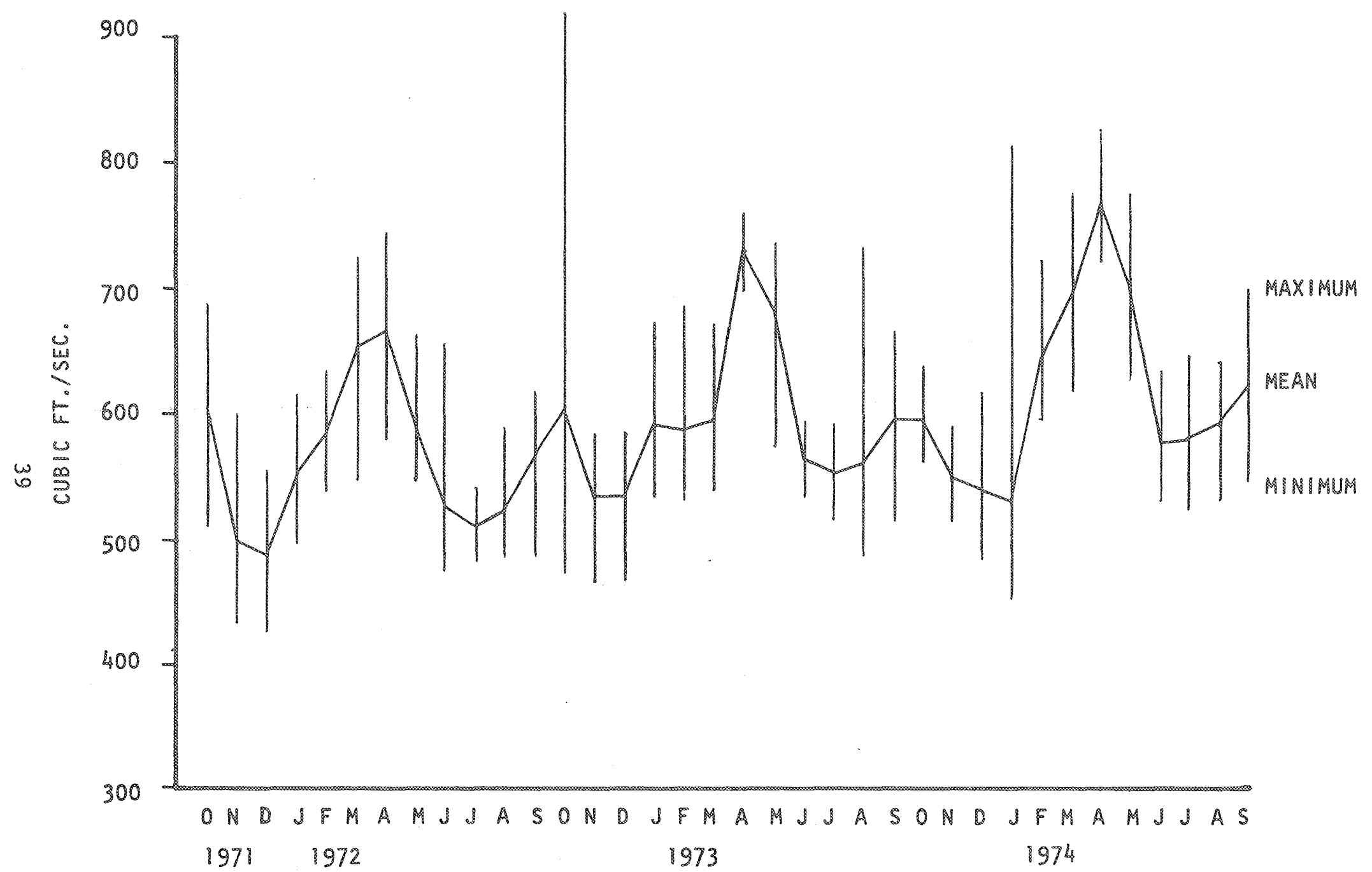


FICURE 5. MONTHY KLOW DATA-DLAMO RTVER

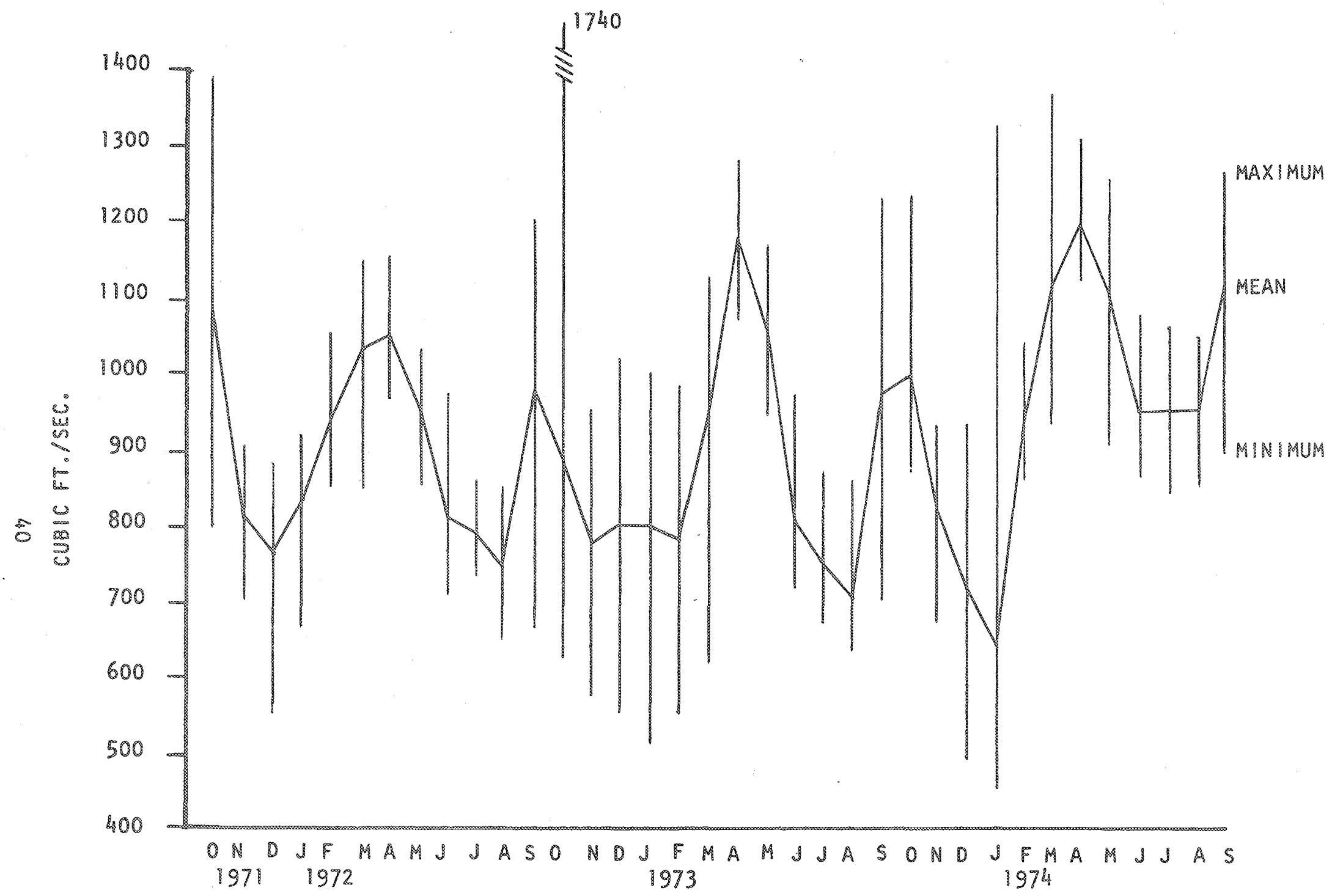


through cooling, and one using the water for cooling tower makeup. The latter use is probably not feasible owing to the high salt content. The former use is probably feasible only for plants close to the sea, and may be limited by a variery of environmental concerns.

\section{Suitability of Irrigation Drain Water for Power Plant Cooling}

While the previous analysis has shown that ample quantities of agricultural waste water exist in the Imperial Valley to support major electric power plant development, the suitability of this water for cooling purposes was not addressed. The purpose of this section is to briefly examine that question.

Several pieces of information will be compared to place the problem in context. Fron the Regional Water Quality Control Board, we have obtained analyses of drain water at four locations in the Imperial Valley, one on the Alamo River near its mouth, and three at various points on the New River. These data are averages of measurements taken over a pexiod of several years. In addition to those values shown in Table 10, a number of constituents such as insecticides and other trace compounds are included in the RWQCB data. Also shown in Table 10 are data for agricultural drain water in the Palo Verde Valley, which is intended to be used for cooling towers at the planned Sundesert Nuclear Plant. Also shown are values estimated for waters that might be used by the San Joaquin Nuclear Project. These water analyses are shown next to the upper-linit values given in Warer Quality Criteria 1972 (a handbook-type publication of the National Academy of Sciences) for brackish water to be used for makeup in recirculating cooling systems.

The basis for the Water Quality Criteria numbers are not well referenced. (While called "brackish", the TDS is actually near that of sea water.) The problems that might come about through exceeding the trace metal limits are unspecified, for example. Alkalinity of the drain water exceeds the stated limit (as does $\mathrm{HCO}_{3}$, a related value), but this can be 
TABLE 10

Water Quality Comparison

(values in ppm)

\begin{tabular}{|c|c|c|c|c|c|c|c|}
\hline Constituent & $\begin{array}{l}\text { Water } \\
\text { Quality } \\
\text { Criteria }\end{array}$ & $\begin{array}{l}\text { Alamo } \\
\text { River }\end{array}$ & $\begin{array}{c}\text { New } \\
\text { River } \\
\text { (Border) }\end{array}$ & $\begin{array}{l}\text { New } \\
\text { River } \\
\text { (Brawley) }\end{array}$ & $\begin{array}{c}\text { New } \\
\text { River } \\
\text { (Westmore) }\end{array}$ & $\begin{array}{c}\text { San } \\
\text { Joaquin }\end{array}$ & $\begin{array}{l}\text { Palos } \\
\text { Verdes }\end{array}$ \\
\hline $\begin{array}{l}\text { Silica } \\
\left(\mathrm{S}_{i} \mathrm{O}_{2}\right)\end{array}$ & 25 & 10.2 & 19.8 & 15.5 & 12.9 & 21 & $?$ \\
\hline $\mathrm{A} 1$ & 0.1 & $\mathrm{~N} / \mathrm{A}$ & $\mathbb{N} / \mathbb{A}$ & $\mathrm{N} / \mathrm{A}$ & $\mathbb{N} / \mathrm{A}$ & $?$ & $?$ \\
\hline $\mathrm{Fe}$ & 0.5 & .04 & 1.15 & .02 & .03 & $?$ & $?$ \\
\hline Mn & .02 & N/A & .178 & $\mathbb{N} / \mathrm{A}$ & $\mathrm{N} / \mathrm{A}$ & $?$ & $?$ \\
\hline $\mathrm{Ca}$ & 420 & 198 & 224 & 222 & 222 & 90 & 130 \\
\hline $\mathrm{HCO}_{3}$ & 140 & 227 & 273 & 280 & 259 & 292 & 297 \\
\hline $\mathrm{SO}_{4}$ & 2700 & 849 & 743 & 812 & 797 & 2385 & 580 \\
\hline $\mathrm{Cl}$ & 19000 & 720 & 1783 & 1400 & 1202 & 1786 & 370 \\
\hline TDS & 35000 & 2534 & 4196 & 3685 & 3288 & 7000 & 1660 \\
\hline Hardness & 6250 & 997 & 1084 & 1002 & 1000 & $?$ & 500 \\
\hline Alkalinity & 115 & 194 & 224 & 229 & 220 & $?$ & $?$ \\
\hline
\end{tabular}


controlled through pretreatment. At Sundesert, for example, limemsoda softening and acid treatment are planned. These are relatively inexpensive processes, and are comonly used.

Of more concern are the organic substance, nutrients, and so forth which are found in the drain waters, and for which no standards are given. These can lead to foaming, algae growth and other fouling problems in cooling towers. One engineer has referred to water treatment in these terms: "Mach of this is black art, conducted by Merlins under cover of darkness." An exact statement of what will be necessary to use drain water in cooling towers cannot be made without site-specific and designspecific information. One can reason as follows, however. In many places including the City of Burbank, for example, municipal sewage is treated and part of the effluent is used for makeup cooling water in the City's generating plant. The cost of treatment of the sewage is reported as \$40-50/acre-foot. It is doubtful if even the New River, contaminated as it is by Mexicali sewage, would require a higher level of treatment.* If we use the Burbank number as an upper limit, then cooling water treatment at a geothermal plant would cost no more than $0.4 \mathrm{mills} / \mathrm{kw}-\mathrm{hr}$, a small increment to the cost of power generation. Probably the cost would be considerably less, if only filtration, alkalinity and hardness control, anti-foamants, and biocides are necessary. The conclusion seems inescapable that the agricultural wastewaters can be used for cooling purposes.

What other problems may be involved with the use of wastewater? First, the dissolved solids will be concentrated by the cooling towers, and eventually deposits will cause operational problems. The solids level is controlled by discharging some of the water as blowdown. While ordinary power plants often resort to evaporation ponds to dispose of the blowdown, a geothermal plant could probably reinject the blowdown with the residual geothermal brines.

* SDG\&E intends to use Palo Verde Valley drain water, with no more than chemical treatment to soften and control $\mathrm{pH}_{\text {, }}$ in the Sundesert Nuclear Plant. 
Cooling towers permit a very small amount of the water to escape as very fine droplets, called drift. Unlike the evaporated water, the drift contains the dissolved salts and other substances present in the cooling water. This drift, as it returns to the ground, can bring about problems of salt deposition. If the original wastewater has harmful organic substances or organisms, it is conceivable that these too could become hazards in the drift. The environmental review process should uncover problems of this sort, and permit the selection of corrective measures. The question of the use of agricultural wastewater for power plant cooling is addressed in the Draft Environmental Impact Report for the San Joaquin Nuclear Plant, for example. The major inflows to the closed Salton Sea are the irrigation drainage. The effects of diversion of the wastewaters on the Salton Sea have been treated in EQL Memo No. 17.

It is also worth considering whether these drain waters can be used for injection into geothemal reservoirs. Here, no body of empirical information exists. Several concerns have been addressed, however. If mixed with other geothermal brines, a corrosion problem can develop. Because many geothermal brines are quite acidic, they can become very corrosive when oxygen is incroduced. The brines thenselves are free of dissolved oxygen until they are exposed to the air. Surface waters usually contain oxygen, however, and that is the source of the worry. Drain waters owing to their high biological oxygen demand (BOD) are apt to be low in oxygen.

Growth of living organisms in the plumbing and passages in the geothermal reservoirs has been a hypothecated problem. However, in a closed pipe no algae can grow, and most bacteria cannot grow in hot fluids. It is assumed that injection would take place into formations at elevated temperature. The last concern is for the possibility of chemical reactions leading to precipitation and plugging of fine passages. Both theoretical calculations and laboratory experiments can shed light on this issue. It is not known whether such research has ever been carried out. 
The salinity of geothermal waters found in the Imperial Valley vaxies from extremely high $(250,000 \mathrm{ppm}+$ at Niland) to a value considered quite 10w, e.g., 2000 ppm. Even this low salinity is too minera1ized for most purposes. It is beyond the acceptable upper values for municipal or agricultural use. Evaporation in cooling towers is the only major use that has been suggested for the "low salinity" geothermal water.

The production of desalted water from saline sources has been actively investigated and accomplished in many parts of the world. For the more saline waters (over $5000 \mathrm{ppm}$, for example), it is found that distillation processes are superior to others. Because distillation involves the heating of the water, the desalting of geothermal waters has had instinctive appeal, as they flow from the ground already hot. The technical literature on desalting is very extensive, and seawater and wastewater conversion plants with capacities of several million gallons per day exist at several locations. The desalting of geothermal waters is a moxe specialized endeavor, however, about which is less known.

One of the foremost authorities on desalting, Prof. A. D. K. Laird of UC, has published a concise summary of the technology.* In a separate publication** he has specifically considered the problem of desalting geothermal waters.

It is observed that large-scale desalting processes divide themselves into two classes, nembrane and distillation. Membrane processes generally use electricity (directly as current or to drive pumps) to accomplish the separation. Electricity is electricity, regardless of how it is produced. If membrane desalting of water is desirable in the

"Laird, A. D. K., "Desalting Technology," California Water, UC Press, Berkeley, 1971.

*Haird, A. D. K., "Water from Geothermal Resources," Geothermal Energy, ed. by Kruger and otte, Stanford Univ. Press, 1973. 
Imperial Valley, that would be true independent of whether the process is associated with geothermal development. In a recent survey of desalting technology, as applied to agricultural wastewater, * it was found that a membrane process (reverse osmosis) cost $\$ 0.60-0.70$ per 1000 gallons to produce water at a rate of ten millions of gallons per day. In more familiar agricultural terms, this corresponds to a water cost of $\$ 200-$ 230 per acre-ft. Because such plants are modular, further economies of scale are unlikely. The electrodialysis membrane process was estimated to produce at a cost of over $\$ 300$ per acre-ft. As has been observed, however, because geothermal water could arrive at a water plant preheated, distillation processes may hold more promise for them.

The simplest distillation process that can be imagined at a geothermal power plant is to condense and capture the exhaust steam. For power plant efficiency, condensers are generally used. It is usually the case that the condensed steam is then used in the plant's cooling towers for makeup. The least expensive form of condenser is the contact condenser, where the cooling water is mixed with the steam, and the condensate leaves the condenser mixed with the coolant. For purposes of $\mathrm{H}_{2} \mathrm{~S}$ control, the new plants at the Geysers will have to abandon this simple system and go to surface condensers, where the condensate and coolant are separated by a solid wall. This is the usual form of condenser used in fossil and nuclear power plants. At the Geysers the condensate will then flow to the cooling towers, and could be subjected to chemical treatment if necessary. If, instead, some other source of poor quality water were available to use as coolant, the condensate (distilled water) could be put to a beneficial use. The cost associated with water production in this mode is the cost differential involved in substituting surface condensers for contact condensers, and the cost of providing the external source of cooling water. In a normal power plant, surface condensers cost between $\$ 10$ and $\$ 15$ per $\mathrm{kw}$ according to a number of estimates.

*Draft Environmental Impact Report, Revised, San Joaquin Nuclear Project, Appendix K, Dept. of Water and Power, City of Los Angeles, 1976. 
In a geothermal plant, however, the heat reject rate is perhaps three times as great as in a fossil plant. Thus the cost of surface condensers for a $100 \mathrm{MW}$ geothermal plant might be estimated as $\$ 30-45 / \mathrm{kw}$. An offhand estimate has been given that contact condensers cost one half as much as surface condensers. On that basis, changing a geothermal plant from contact to surface condensers, in order to preserve condensate, costs from $\$ 15-23 / \mathrm{kW}$. For a $100 \mathrm{MW}$ plant, this equals 1.5 to $2.3 \mathrm{mil1}$ ion dollars, and produces approximately 6000 acre-ft of water annually. For 12 percent annual cost of capital, this amounts to a water cost (capital only) of $\$ 30-45 /$ acre-ft. The cost of supplying agricultural drain water to cool a geothemal power plant in Imperial Valley is not apt to exceed $\$ 10 /$ acre-ft. Thus a supply of distilled water, amounting to 6000 acreft/year from a $100 \mathrm{MW}$ power plant, could be available at an approximate price of $\$ 40-50$ per acre-ft. It is possible that some treatment would be necessary to rid the water of hydrogen sulfide, boron, or other volatile substances that might exist in the original geothermal fluid. Only we11-by-well testing can yield information on the necessity for water treatment and on the cost of treatment.

Use of the power plant condensate in this way is the cheapest souxce of pure water available from geothermal resources. The steam, however, may comprise only 10 to 20 percent of the total flow from a well. To obtain a greater percentage, special desalting equipment is required. Laird has estimated that perhaps 80 percent of the well flow could be converted to fresh water. While many types of equipment and combinations of power- and water-producing cycles can be envisioned, most of the waterproducing equipment is of the multi-effect or multi-stage distillation type. The design conditions for geothermal desalting are different than for seawater desalting, because the brine is supplied at a high temperature. Nonetheless, the basic processes are the same, and seawater desalting equipment offers a good guide as to the size and cost of geothermally oriented equipment. In an earlier review it was pointed out that

*Goldsmith, M., Geothermal Resources in California, EQL Report No. 5, Caltech, Pasadena, 1971. 
a good rule of thumb for the capital cost of desalting plants was one dollar per gallon-per-day (gpd) capacity. Professor Laird had expressed the hope that continued development would reduce this cost in future years. Unfortunately, the opposite has taken place. Some costs attributed to recent construction have indicated that a figure of two dollars per gpd capacity is now appropriate. Data shown in the San Joaquin Nuclear Project EIR bear this out. Thus, even the capital cost for desalted geothermal brine, excluding all wells, operating costs, etc., is $\$ 0.60$ to $\$ 0.90$ per 1000 gallons, or $\$ 190$ to $\$ 290$ per acre-ft. It does not seem likely that geothermal brine desalting will be economic in the Imperial Valley unless major reductions in capital cost can be realized. It is true, however, that by blending the desalted water with other waters of poor or unusable quality, the effective cost of the now useful water can be lowered. For example, a 50-50 blend of $2000 \mathrm{ppm}$ drain water and desalted water results in a $1000 \mathrm{ppm}$ mix at an effective price of $\$ 100-150$ per acre-ft. If the water from the Colorado River continues to increase in total dissolved solid from $900 \mathrm{ppm}$ to $1200 \mathrm{ppm}$ at Imperial Dam, the value of $900 \mathrm{ppm}$ could be reattained by mixing 25 percent desalted water with 75 percent river water. This would make the effective cost of the improved water blend $\$ 50-75 /$ acre-ft.

The use of desalted water for municipal use is more likely than for agriculture. Agriculture may not be profitable using such expensive water, unless very efficient means of using the water are developed (drip irrigation, etc.). An average value of consumption in municipal use is 200 gpd per capita. Thus the cost of desalted water in the cities and towns might amount to 10 or 15 cents per day per household. It is possible that residents might be willing to pay some premium for improved water quality. To expand on this theme, the condensate from only 250 MW of geothermal power plant capacity would provide 15,000 acre-ft per year, which is the approximate amount required for the population of Imperial County. The cost of producing that first increment of water from power plant condensate 
may not be too great, as previously noted, and the major cost might be the transport and distribution of the fluid. Blending, which would be required technically in any case, could serve to reduce the premium paid for the better water. Thus, geothermal development may offer the townspeople of Imperial County a way to substantially upgrade their municipal water supply at a feasible cost. The possibility would seem to be worth a detailed examination.

X Production of Chemicals from Imperial Valley Geothermal Resources

A very useful report on the subject has been recently (February 1975) prepared by Hazen Research, Inc. with the title, "Process Technology for Recovering Geothermal Brine Minerals," Bureau of Mines Open File Report 35-75. The report covers several subjects. First, analyses of waters from several geothemal wells and springs in the western U.S. are shown. An extensive review of existing process technology for the minerals found in geothermal brines is included. The study goes on to consider what processes might be appropriate for obtaining minerals from geothermal brines, problems that might be encountered, and market demand for the products. Anyone interested in the subject could profitably spend a few hours with this document. It would seem that chemical recovery has been put in the most favorable light in the report, and yet the economic prospects are marginal. Thus chemicals irom geothermal fluids do not represent a bonanza, but xather only a possibility for a profitable enterprise.

Hazen arrives at many important conclusions, but one is of particular interest to Imperial County. They conclude that mineral recovery from dilute brines is probably not profitable, and their promising processes include only the Salton Sea (Niland) KGRA fluids as feedstock. Simply put, this conclusion indicates that if mineral recovery is to become commercially practical, it will be done at Niland and not at the other KGRA ${ }^{B}$ in the County or elsewhere in the western U.S. 
Chemical analysis of the fluid at Niland (Sinclair No.4) and a market survey caused Hazen to conclude that only iron, manganese, lead, zinc, strontium, barium, 1ithium, bromine and ammonia were "valuable constituents", but consideration was given to sodium, potassium and calcium chloride production should marketing and transportation considerations make it attractive.

To focus the discussion, Hazen chose a numerical example of production of "Sinclair No. 4" brine at the post-flash rate of 10 million gallons/day. This is the output from approximately 10 wells. In Hazen's Table 26, reproduced here, the volume and dollar value of the chemicals are shown for that production rate. In the table below, the present U.S. consumption of several of these chemicals is compared to the Hazen production example.

\section{U.S. Consumption (approximately) tons/year}

Sodium Chloride

Potash

Lithium

Manganese

Strontium
$50 \times 10^{6}$

$5 \times 10^{6}$

$2 \times 10^{4}$

$2 \times 10^{6}$

$2 \times 10^{4}$
Production from ten million gpd Sinclair No. 4 (approx.) tons/year

$3 \times 10^{6}$

$6 \times 10^{5}$

$2 \times 10^{4}$

$4 \times 10^{4}$

$2 \times 10^{4}$

Hazen assumed that where a domestic shortfall in production exists al1 the product would be salable at current prices; where ample capacity exists, they assumed a reduced selling price. In some cases the assumed production complex would only dent the market; in other cases production approximately equals the present market.

Hazen postulated a production process for the chemicals, and per-.. formed a cost analysis, assuming no cost for the feedstock (as if it were an unwanted by-product of electrical production, for example). The plant equipment was estimated to cost nearly $\$ 6$ million, with a total plant 
TABLE 11

(After Hazen, 1975)

Mineral Values Contained in Sinclair No. 4 Brine

Basis: Post-flash flow of $10 \times 10^{6} \mathrm{gal} / \mathrm{day}$ and 330 days/year operation.

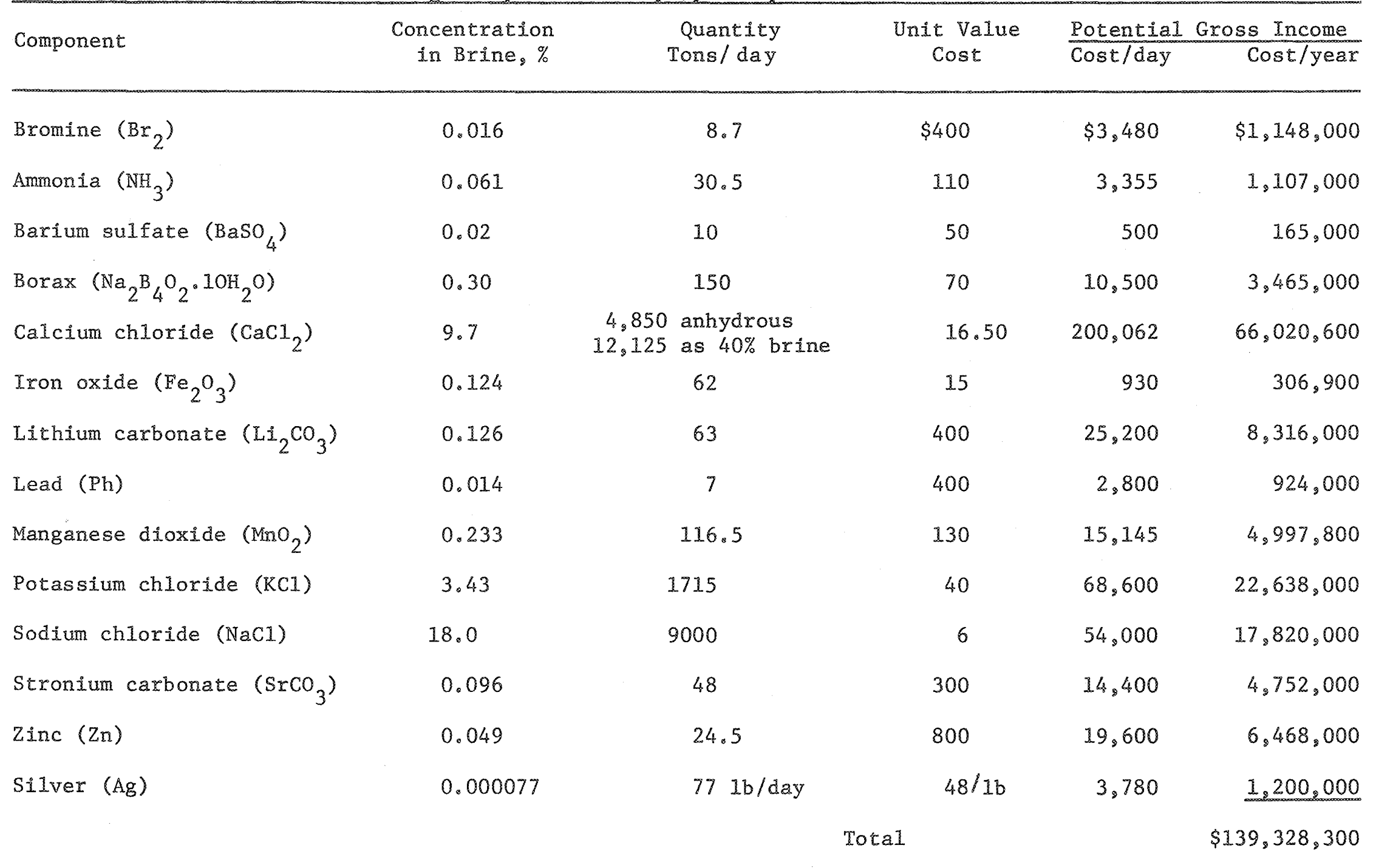


investment of $\$ 30$ million. The annual revenue was estimated to be $\$ 20$ million, and Hazen concludes that this is within the normal ratios for chemical plants.

They calculate a 15 percent return on investment for the plant. Operating personnel for the plant is estimated to be seven persons/shift, plus supervision. Clearly this chemical plant is capital intensive, not labor intensive.

To capture the chloride salts, the water would have to be removed from the chemical plant outflow. Hazen estimates that removal by steam evaporation is probably not profitable. (The process is much like a water distillation process.) The annual cost is $\$ 13$ million (\$0.87/ton evaporated), based on an investment of $\$ 25$ million. Using solar ponds ( 3000 acres) requires an investment of $\$ 30$ million (1ined ponds) with end cost of $\$ 0.31 /$ ton evaporated, or $\$ 9$ million investment (unlined ponds) and cost of $\$ 0.09 /$ ton evaporated. While occupying a large area, the solar ponds appear more profitable. Again, we must remember that the commerclal practicality of salts production (calcium, potassium, and sodium chlorides) depends on marketing and transport. Hazen points out that production of caustic soda and soda ash from salt may be likely candidates. Note that chloride chemical processes are often large consumers of electricity, thus the tie-in with geothermal may make sense. 